\title{
Meshing Sustainability with Satisfaction: An Investigation of Residents' Perceptions in Three Different Neighbourhoods in Chengdu, China
}

\author{
Qi Zhang 1,2,3,*, Esther Hiu-Kwan Yung ${ }^{3}$ and Edwin Hon-Wan Chan ${ }^{3} \mathbb{D}$ \\ 1 Wuhan Land Use and Urban Spatial Planning Research Center, Wuhan 430000, China \\ 2 College of Architecture and Urban Planning, Tongji University, Shanghai 200092, China \\ 3 Building and Real Estate Department, The Hong Kong Polytechnic University, Hung Hom, Kowloon, \\ Hong Kong 999077, China; esther.yung@polyu.edu.hk (E.H.-K.Y.); edwin.chan@polyu.edu.hk (E.H.-W.C.) \\ * Correspondence: zhangqi@wlsp.org.cn
}

\section{check for} updates

Citation: Zhang, Q.; Hiu-Kwan Yung, E.; Hon-Wan Chan, E. Meshing Sustainability with Satisfaction: An Investigation of Residents'

Perceptions in Three Different Neighbourhoods in Chengdu, China Land 2021, 10, 1280. https://doi.org/ $10.3390 /$ land10111280

Academic Editors: Nikos A. Salingaros, Alexandros A. Lavdas, Michael W. Mehaffy and Ann Sussman

Received: 13 October 2021

Accepted: 19 November 2021

Published: 22 November 2021

Publisher's Note: MDPI stays neutral with regard to jurisdictional claims in published maps and institutional affiliations.

Copyright: (c) 2021 by the authors. Licensee MDPI, Basel, Switzerland. This article is an open access article distributed under the terms and conditions of the Creative Commons Attribution (CC BY) license (https:// creativecommons.org/licenses/by/ $4.0 /)$

\begin{abstract}
Can sustainability and liveability be simultaneously pursued the neighbourhood level? Adopting neighbourhood satisfaction as a proxy to indicate liveability at the neighbourhood scale, this paper investigated how the residential subjective perception of sustainability factors interacted with neighbourhood satisfaction in the context of three different neighbourhoods in Chengdu, China. This began with a comprehensive literature review to construct the neighbourhood sustainability framework. Then, a total of 510 cross-sectional questionnaire surveys was conducted in Chengdu. Logistic regression was employed to investigate significant associations. The findings revealed that the 'sense and habit of energy saving' is the only sustainability factor that is negatively associated with neighbourhood satisfaction in commodity-housing neighbourhood. Compared with intangible factors, tangible or physical sustainability factors are more likely to contribute to improving neighbourhood satisfaction and suppressing moving intention. The study also evidenced the contextual differences of significant associations among danwei, resettlement, and commodity-housing neighbourhoods coexisting in transitional China. This calls for adaptive and contextual rather than standardized, top-down strategies for developing sustainable neighbourhood planning to simultaneously promote sustainability and liveability in Chengdu, China. Finally, a specific contextual framework was provided as policy implications for developing local and adaptive solutions.
\end{abstract}

Keywords: neighbourhood; sustainability; framework; China; perception; liveability

\section{Introduction}

Rapid urbanization and population growth has, in turn, boosted economic development in terms of infrastructure and housing demand; meanwhile, it has comprehensively challenged sustainable development in the twenty-first century. The United Nations has forecasted that $66 \%$ of the total population will be in urban by 2050 , compared with $54 \%$ in 2014 [1]. It has also stressed that as the world continues to urbanize, sustainability challenges will increasingly be concentrated in cities, particularly in low- and middle-income countries, where the pace of urbanization is faster. López Moreno et al. highlighted that urban development has been facing sustainability challenges in the following four areas: environmental sustainability, competitiveness and productivity, liveability, social inclusion, and equity [2]. Among the four areas, sustainability and liveability are closely correlated at various layers. Liveability is defined as "the degree to which a place supports quality of life, health and well-being" [3]. Sustainability is the interconnectedness of environmental, economic, and social dimensions from local to global scales from an intergenerational perspective [4]. Liveability is significantly derived from the urban environmental quality of a dwelling, neighbourhood, and city. Meanwhile, various sustainability factors, such as access to open space, air quality, and noise, may contribute to the satisfaction level associated with living at different urban scales [5]. On one hand, the close mutual relationship of 
these factors determines that it is impractical to separately develop these two paths. On the other hand, their latent conflict makes it complicated to simultaneously facilitate their development. For instance, the paradox of urban desirability versus suburban liveability in compact cities implies the contradiction between sustainability and liveability [6]. Thus, to effectively tackle the intrinsic challenges, it is crucial to deepen our understanding of the association between sustainability and liveability.

Theoretically, to date, there is no global consensus on specifying the associations between sustainability and liveability, although related issues have been investigated by many scholars in recent decades. The resemblances and discrepancies between these two concepts, as summarized in [7], are shown in Table 1. Simultaneously developing sustainable and liveable cities is complicated, as it epitomises the crucial nexus of urban planning, sustainable development, built environment, and public perception [8,9]. This issue has attracted attention in the recent decades since the latent conflict between liveability and environmental sustainability was found in several developed countries, such as Australia [5]. Additionally, Portney stated that liveability and sustainability are practically indistinguishable [10]. Lowe et al. identified the mismatch among different researchers' investigations on liveability and sustainability indicators and the barriers hindering their transformation into policies in the context of Australia [3]. Furthermore, Leach et al. argued that sustainability and liveability are not necessarily reciprocal [11]. Generally, there is a need for interventions that enhance rather than compromise well-being and leverage the sustainability and liveability of their cities. Although it is difficult to clearly distinguish these two concepts, it is significant and possible to investigate their associations regarding certain indicators or factors.

Table 1. Resemblances and discrepancies between sustainability and liveability (source: [7]).

\begin{tabular}{|c|c|c|c|}
\hline & Aspects & Sustainability & Liveability \\
\hline \multirow{3}{*}{ Resemblance } & $\begin{array}{l}\text { The characteristic of } \\
\text { definition }\end{array}$ & \multicolumn{2}{|c|}{ Intrinsically normative, subjective, and ambiguous } \\
\hline & Political influence & \multicolumn{2}{|c|}{$\begin{array}{l}\text { Has key framing influences on public policy in } \\
\text { development }\end{array}$} \\
\hline & General objective & \multicolumn{2}{|c|}{$\begin{array}{l}\text { They both have a profound focus on needs and an } \\
\text { ability to satisfy them }\end{array}$} \\
\hline \multirow{3}{*}{ Discrepancy } & $\begin{array}{l}\text { The relationship it } \\
\text { studied }\end{array}$ & $\begin{array}{l}\text { Not only current } \\
\text { generation but also } \\
\text { long-term, } \\
\text { intergenerational } \\
\text { conditions }\end{array}$ & $\begin{array}{c}\text { Environment and quality } \\
\text { of life, especially focusing } \\
\text { on the needs of the } \\
\text { present }\end{array}$ \\
\hline & $\begin{array}{l}\text { Human-centric } \\
\text { emphasis }\end{array}$ & $\begin{array}{l}\text { Less or indirect } \\
\text { human-centric } \\
\text { emphases }\end{array}$ & $\begin{array}{c}\text { More and direct } \\
\text { human-centric emphases }\end{array}$ \\
\hline & Theoretical implication & $\begin{array}{l}\text { Provides a benefit to } \\
\text { societal and external } \\
\text { systems }\end{array}$ & $\begin{array}{l}\text { A reflection of 'quality of } \\
\text { life', 'well-being', and/or } \\
\text { the satisfaction of the } \\
\text { needs of 'the people'. }\end{array}$ \\
\hline
\end{tabular}

Since neighbourhood satisfaction has been adopted as the most common measure and a proxy to indicate liveability [12], investigating the association between satisfaction and sustainability factors at a neighbourhood scale could be the key breakthrough point. In recent decades, the importance of the neighbourhood to the liveability and sustainability of the whole city has been investigated by many studies $[12,13]$. As host of major spaces where human activities occur, a city is considered sustainable only if neighbourhoods and building environments meet sustainability criteria [14]. A liveable city is described as having strong neighbourhoods and sufficient necessary supporting facilities within acceptable walking distance. It should also contain a network of attractive public spaces and buildings, 
possess the characteristics of affordability, vibrancy, and cleanliness, and nurture a diverse street culture [15]. Meanwhile, the importance of people's perceptions in contributing to neighbourhood satisfaction and sustainability implies their role in investigating these associations. Sustainable development goals can only be realized if governments actually implement the necessary policies or the public behaves in a sustainable way by following the guidelines. Since a neighbourhood is the nearest unit of a city to people's daily lives, neighbourhood sustainability becomes closely associated with people's actions and behaviour. The association between perception and action has been widely discussed in many studies, particularly the relationship between residential satisfaction and moving out. The moving intention of residents has been mentioned in other studies to indicate whether neighbourhoods meet both the sustainable and liveable criteria in western countries [16]. Asking residents to indicate their 'intention to stay or not' was previously adopted in investigating residential moving intention [17]. Therefore, people's perceptions have a critical impact on the sustainability and liveability of a neighbourhood, as well as a whole city.

Very few studies have investigated the four dimension of sustainability factors in the different neighbourhood contexts in China. Given many sustainability assessment tools for neighbourhoods, such as LEED (-ND), BREEAM (Communities), TAHER, CASBEE (-UD), DGNB (-NSQ), and Beam Plus ND, have taken effect globally, systematically and locally reviewing the effect of the included factors in shaping neighbourhood development is important. China is one of the largest and quickest developing countries and has undergone significant sociopolitical transitions since the 1980s [18]. Challenges such as traffic congestion, land overdevelopment, declining social capital, environmental deterioration, urban sprawl, and social inequality, have spotlighted neighbourhood sustainability issues [19]. Thus, corresponding policies and guidelines were issued by both national and local governments to direct urbanization paths with the goal of achieving sustainability and liveability. Many studies have demonstrated how to adapt sustainable strategies to local contextual conditions $[4,20]$. Others have investigated neighbourhood sustainability and liveability and neglected the contextual variation in terms of neighbourhood typology. They have either only focused solely on gated [21] or migrant [22] neighbourhoods or broadly researched the total population of all neighbourhoods [23]. Since sustainability and liveability have found their way into mainstream public policy and transition studies [7], it is urgent to research these two concepts and their interaction in the context of Chinese cities. Thus, there is a gap in exploring the relations between sustainability, including its four dimensions, and liveability in the context of various neighbourhoods in China.

To fill this gap, this research focused on systematically investigating the significant associations between sustainability and residential satisfaction at the neighbourhood level by conducting three case studies in China. Unlike previous research, which has focused on a single dimension, either social, economic, or environmental, this study first constructed an integrated neighbourhood sustainability framework consisting of a wide range of sustainability factors through an extensive literature review of both the academic and practical literature. Then, a questionnaire survey with a total of 49 questions was designed based on selected factors of the framework. Afterwards, on-site questionnaire surveys were distributed to collect residents' perceptions of the selected issues, as well as their socioeconomic characteristics. Based on the results, logistic regression modelling was adopted to examine the significant associations among perceived sustainability, neighbourhood satisfaction, and moving intention. Lastly, a contextual framework was proposed to develop adaptive sustainable neighbourhood planning, promoting sustainability and liveability simultaneously in the three neighbourhoods.

\section{Theoretical Framework}

To investigate the relationship between sustainability and satisfaction at the neighbourhood level in the context of urban China, understanding the involved concepts and context is fundamental. Thus, this section introduces key concepts, different sustainability 
factors, the relationships among these investigated factors, and the socioeconomic-political context of China within which the issues are discussed.

\subsection{Neighbourhood Sustainability}

Sustainability concerns how communities at various levels envision and pursue social and natural well-being [24]. The three core objectives of sustainability science have been identified by Kates et al. as (1) understanding the fundamental interactions between nature and society; (2) guiding these interactions along sustainable trajectories; and (3) promoting the social learning that is necessary to navigate the transition to sustainability [25]. The 'sustainable cities and communities' goal was selected as the 11th of the 17 sustainable development goals issued by the United Nations [26]. Currently, there is a wide consensus that sustainability has four main dimensions in the context of urban planning: social (SC), environmental (EV), economic (EC), and institutional (IN) [4]. Grybaite and Tvaronavičiene and Ciegis et al. argued that as the newly added dimension, the institutional dimension has become emergent, important, and relatively weak in managing the implementation of sustainable development $[27,28]$.

A city is considered sustainable only if its components, particularly neighbourhoods and built environments, meet the sustainability criteria. There are a number of commonly used definitions of neighbourhoods, such as "a geographically localised community located within a larger city or suburb" or "a separately identifiable area within a community retaining some quality or characters which distinguishes it from other areas" [14]. By referring to the newly issued China standards and administrative boundaries, an area with a radius of $400 \mathrm{~m}$, which is a $5 \mathrm{~min}$ walking distance [29], was selected to define the scale of neighbourhoods in this study.

The four pillars of sustainability have hierarchical implications at the neighbourhood level. Gilbert et al. demonstrated that "social sustainability requires that the cohesion of society and its ability to work towards common goals be maintained" and "Individual needs, such as those of health and well-being, nutrition, shelter, education and cultural expression should be met" [30]. On a neighbourhood scale, it covers sense of place, social interaction, neighbourhood stability, security and safety, networks in the neighbourhood, and participation in collective groups, etc. [31]. Economic sustainability means the efficient and responsible usage of resources for long-term benefits [32]. On a neighbourhood scale, economic sustainability includes growth potential, jobs and opportunities, smart efficiency, and information circulation [33]. Environmental sustainability "seeks to improve human welfare by protecting the sources of raw materials used for human needs and ensuring that the sinks for human wastes are not exceeded, to prevent harm to humans" [34]. On a neighbourhood scale, this covers the optimization of building energy performance, solar orientation, streets and transport, light pollution reduction, etc. [35,36]. Institutional sustainability means an institutional consensus involving agreements and strategies reflecting sustainable development concepts. Based on previous institutional indicators, this research categorizes the institutional sustainability of a neighbourhood into policymaking, engagement, and partnership [37,38].

Thus, the authors built a theoretical framework based on intensive reviews of both academic papers and six selected industrial tools of sustainability evaluation and specified factors under the four sustainability pillars. The framework was included in the authors' previously published paper [39] generated from the same project. To provide a brief overview of the theoretical framework, the different factors are shown in Appendix A Table A1. The framework laid the theoretical foundations for subsequent data collection and analysis.

\subsection{Neighbourhood Satisfaction and Liveability}

The relationship between people and their residential environment represents a classical environmental psychology research issue. Most notably, neighbourhood satisfaction has emerged as a cornerstone of subjective neighbourhood research [40-44]. The Institute 
for Social Research (ISR) of the University of Michigan suggests that satisfaction with living can be viewed at multiple levels of analysis [45-50]. This study only focused on the level of satisfaction with the neighbourhood.

Generally, the strong alignment between neighbourhood satisfaction and liveability was underlined in a previous study [51]. A satisfactory neighbourhood is normally perceived as a liveable neighbourhood. There is a consensus in the urban planning and housing literature that conceptualizes liveability as an urban condition derived from interactions with the urban environment [52]. Neighbourhood satisfaction is the most common measure used in empirical studies to assess liveability within built environments for urban planning purposes [11]. In this regard, liveability in the urban setting is the degree of residential satisfaction towards residents' subjective and objective living environment [53].

\subsection{Relationships among Neighbourhood Sustainability, Satisfaction, and Moving Intention}

As demonstrated by Hamersma et al., it is essential to investigate the subjective perception of residents' neighbourhood satisfaction with neighbourhood elements for a better understanding of sustainability and liveability [54]. As shown in Table 1, sustainability and liveability are interrelated but may not always move forward hand in hand. Although the public may support sustainability principles, it has been argued that several sustainability initiatives, such as high-density developments, have negative impacts on individuals' quality of life [41]. In sum, there may be a latent divergence between sustainability and residential quality of life that reduces the attractiveness of promoting sustainable development to the general public. Another similar example is the conflict between the reduction in energy consumption and comfort of personal lifestyle. This is one of the prominent gaps between current sustainable development strategies and practical societal motivations, which hinders sustainable urban development [55]. As a result, perhaps the scarcity and sacrifice of sustainable development is inherently uninspiring and may be more likely to induce apathy rather than active engagement and change [56,57].

In this sense, if current sustainable efforts go against liveability and consequently lack attractiveness to residents, it would be increasingly challenging to form a societal collaborative action in realizing sustainable development [58]. Therefore, to further facilitate sustainable urban development, it is imperative to make sustainable neighbourhood planning attractive, inspirational, and exciting to the neighbourhood and ensure residents' active engagement. Additionally, satisfaction degree is found to be significantly associated with moving intention. Speare articulated that residential satisfaction is related to the wish to move and to actual mobility [59]. Therefore, moving intention is associated with population stability, which can strengthen community social cohesion and collective efficacy, as well as deter crime and disorder [60,61]. Additionally, moving intention is arguably associated with the stability of the residential population, which affects social sustainability [62]. Thus, neighbourhood sustainability, satisfaction, and moving intention are interrelated. However, as shown in Figure 1, their relationships remain unclear and are yet to be investigated.

Thus, satisfying the residents of transitional neighbourhoods cannot be ignored when navigating the transition to sustainability. In this sense, sustainable neighbourhood planning should consider and enhance liveability to advance sustainable neighbourhood development. To achieve this, understanding the specific sustainability factors that are associated with neighbourhood satisfaction is fundamental. Thus, several specific questions are posed: how and to what extent are they correlated in different types of neighbourhoods in China? Do these correlations reveal universal principles or context-specific issues? 


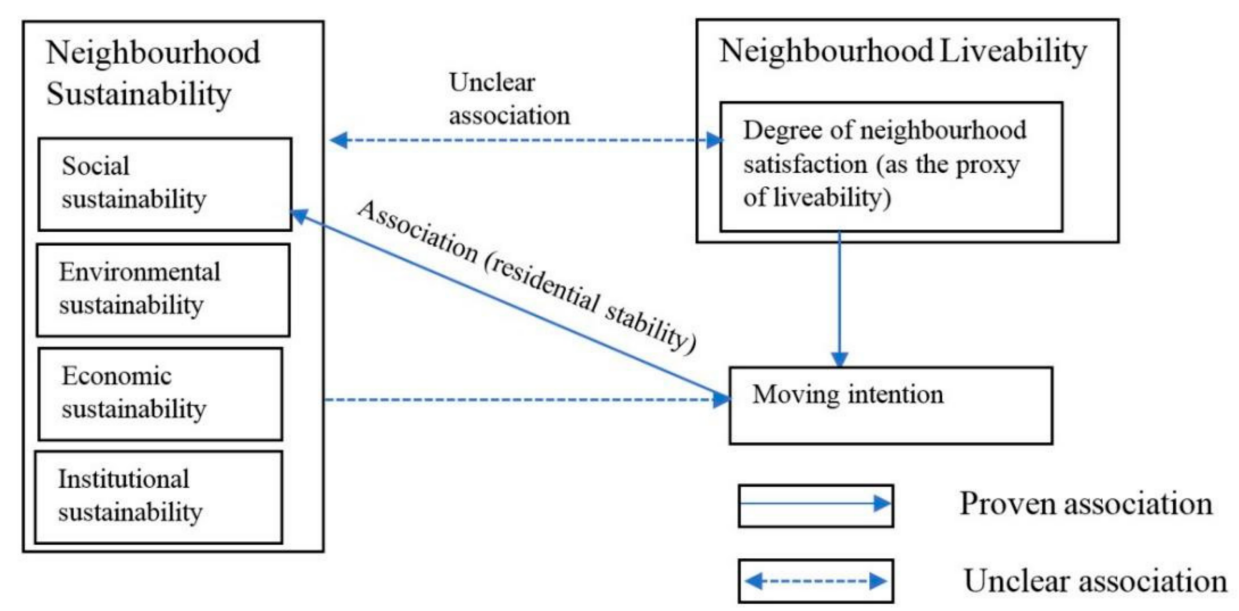

Figure 1. Conceptional framework of theoretical association with neighbourhood sustainability, satisfaction, and moving intention.

\subsection{Neighbourhood Types in Transitional China}

Due to the transition of institutions affecting urban development, Chinese cities have been characterized by the coexistence of different urban forms, neighbourhoods, and housing types [63]. As this study focused on neighbourhoods under transition in the socioeconomic-political context, the types are mainly categorized by institutional aspects rather than spatial characteristics. Specifically, the following three types of urban neighbourhoods were included in this research: work-unit or danwei compounds, commodity-housing estates, and resettlement neighbourhoods [64,65].

One of the major transitions is the ongoing diminishing of the old 'danwei' (work unit) system, which is an institution created in the planned-economy era. Based on the danwei system, a compound of employment that provides both working stations and living accommodation was allocated to the employees. Prior to late 1990s, the danwei compound provided most housing units for the society. Meanwhile, it provided comprehensive and exclusive supportive facilities and services, including shops, parks, medical care, and educational facilities as the welfare of being employed [66]. In 1998, the allocation of accommodation as welfare-oriented housing in danwei was terminated [67]. The 1998 housing reform was a major contributor to the decline of danwei and the proliferation of commodity residential compounds. The structure of the housing system increasingly transformed from old traditional neighbourhoods to new commodity housing. Taking Guangzhou, one of the most populated metropolises in China as an example, when the danwei retrenched as a producer of housing, its share of built residential areas fell from $46.1 \%$ in 1998 to $12.1 \%$ in 2006 [68]. However, there are still many remaining danwei neighbourhoods. They accommodated employees from different organizations, such as the government, universities, professional institutes, military, and state-owned companies. Due to the increasing turnover of residents after the establishment of the housing market and the relief of housing purchase restrictions, heterogenized resident populations rapidly became the emerging characteristic of the neighbourhood profile. This imposed a negative impact on social cohesion, community sense of belonging, and neighbourhood governance [69].

As the housing system has become a market-driven commodity, property-led housing estates have proliferated in both suburban and redeveloped inner-city areas [70] and have recently become the dominant form of residential development in China [71]. Most commodity-housing neighbourhoods are gated communities. In the newly built neighbourhoods, where most residents are property owners, many social sustainability issues are correlated with environmental sustainability to affect privatism and individualism. For instance, the role of the built environment is highlighted by scholars as a more dominant element in affecting sense of community than social interaction [72]. Residents' negative perceptions of the physical environment diminish neighbourhood attachment and can result 
in outmigration from the neighbourhood [73]. Residential stability, which significantly retains social cohesion, suppressing the crime rate [74], can also be affected by the moving intention of residents. Thus, the association between physical and social environments plays a vital role in fostering a sustainable and liveability commodity-housing neighbourhood.

Another transition of residential forms has been the emergence of resettlement neighbourhoods due to rapid urbanization. As urban built-up areas have rapidly expanded, large-scale land acquisitions have been implemented by governments or developers for construction usage. Due to this massive urban expansion, many original farmers lost their farmlands and became urban citizens. According to the policy of land acquisition in the suburban area, a large number of resettlement neighbourhoods have been built to accommodate the affected 'new urban citizens' [65]. Consequently, resettlement neighbourhoods have been comprehensively built in newly developed urban fringe, especially industrial parks. Some scholars have criticized resettlement as a type of involuntary urbanization, the whole procedure of which is dominated by governments. The opinions and demands of affected residents are often ignored [75]. This might threaten social sustainability in several aspects, such as affordable housing, social networks, and sense of belonging. Additionally, from the perspective of public participation, the negative impact of lacking a bottom-up procedure during resettlement threatens institutional sustainability.

One of the key institutional elements affecting the transition of urban neighbourhoods is the Hukou system. The Hukou system is an institutional arrangement employed in Chinese society as a political tool of household registration and population mobility control. It was established in 1958 and compulsorily operated like a boundary, dichotomizing citizens' identities into rural and urban in order to divide the population into rural and nonrural households-essentially, two-tier boundaries of belonging [76]. Thereafter, the Hukou system turned out to be effective in restricting the movement of the population between cities and towns [77,78]. Since the reform in 1978, restrictions of the Hukou system on rural-urban migration have gradually loosened. However, although population mobility between urban and rural areas has been boosted, the uneven policy derived from the Hukou system still comprehensively exists in contemporary urban life. For example, migrants without a local Hukou are still not qualified to receive basic urban services, such as subsidized housing, education, or even a pension in their city of residence [79]. This social phenomenon has become a crucial element for interpreting the demographic transition of neighbourhood residents and derives sustainability challenges at the current stage.

Traditional danwei, resettlement housing, and commodity-housing neighbourhoods widely exist in Chengdu. Chengdu was selected for this research due to (1) its cultural and environmental representation as the national central city in Southwest China; (2) its outstanding political and pioneering position in developing sustainable urban development; and (3) its prestigious image as one of the most liveable cities in China. In 2016, the municipal government launched the 'Building Sustainable Urban-Rural Neighbourhoods' project to provide municipal funding and mobilize public participation for sustainable neighbourhood development. The government has invested approximately RMB 20 million annually to support more than 200 neighbourhoods in fostering sustainable neighbourhoods [80].

\section{Methodology}

\subsection{Case Selection}

'Diverse cases' were selected as the strategy of case selection in this study, as they can illuminate the full range of independent and dependent variables [81]. This is consistent with the major research objective, which is to investigate the association among a wide range of sustainability factors, neighbourhood satisfaction, and moving intention. Meanwhile, selected cases representing these three types can exhibit a wide range of the resident characteristics, as well as issues relating to sustainability and neighbourhood satisfaction. Specifically, three main criteria were adopted for selecting cases in this research:

- It should belong to one of the three representative types of transitional neighbourhoods: traditional danwei, resettlement neighbourhood, and commodity housing [72]; 
- It should be one of the pilot neighbourhoods that received municipal funding to implement 'sustainable neighbourhood building';

- Its spatial scale should be roughly equivalent to a circle area with a radius of $400 \mathrm{~m}$, which is a 5 min walking distance [29].

After reviewing many neighbourhoods, Yulin, Xinyue, and Jinyang were selected for the case study within Chengdu, representing danwei, resettlement, and commodity neighbourhoods, respectively [39]. Their locations and satellite maps are shown in Figures 2 and 3. The basic data described in the following, including population and size, were provided by the corresponding neighbourhood residential committee during the on-site investigation. The various physical and perceived environmental attributes can help avoid the omission of variables, which could lead to biased estimates. This enables a deep investigation of the effect of different neighbourhood characteristics on sustainability and liveability and expands the relevance of the findings to other geographical contexts in China [39].

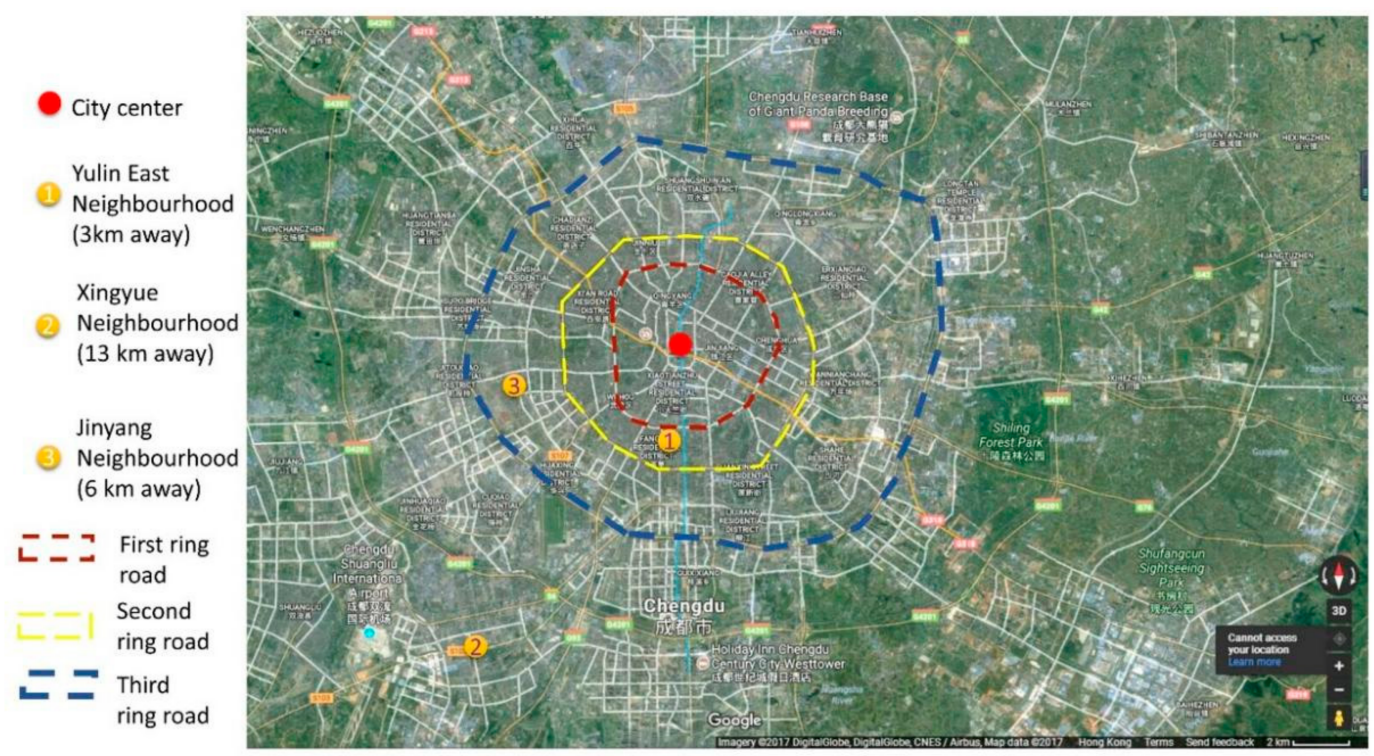

Figure 2. Location of the three neighbourhoods in Chengdu (source: authors' version based on Google Earth map).
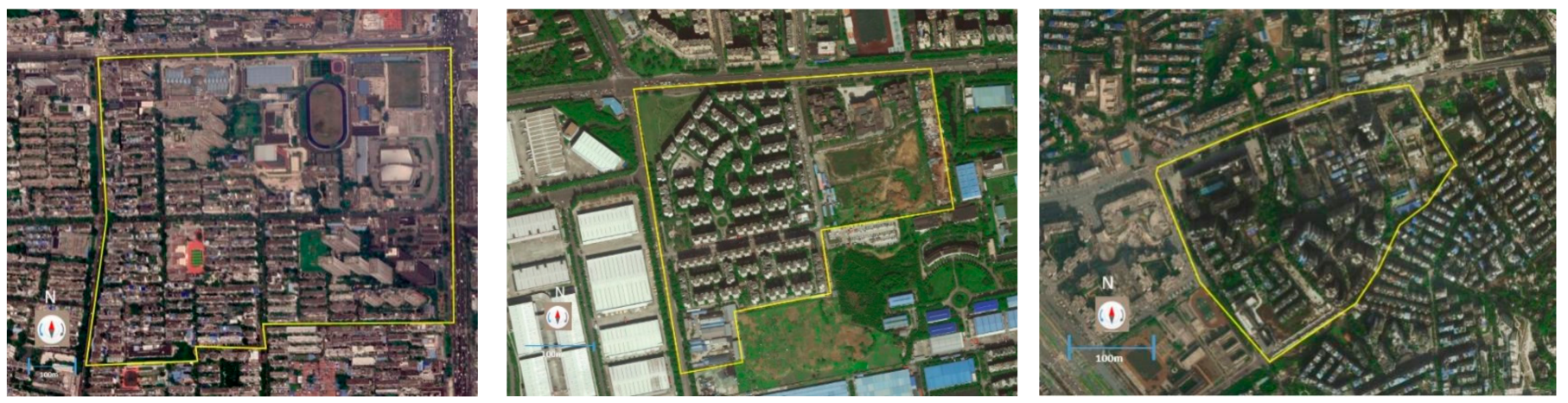

Figure 3. Satellite maps (the same scale) of Yulin, Xingyue, and Jinyang (from left to right) in 2018 (Source: Google Earth).

The Yulin neighbourhood is located in the southern area of Wuhou district between the municipal first ring road and second ring road. It consists of 11,027 inhabitants and covers an area of 45 hectares. As a traditional neighbourhood, the Yulin neighbourhood consists of a total of 14 danweis and 51 yards. Compared to other surrounding neighbourhoods, the infrastructure of Yulin is relatively advanced, and the cultural activities are diverse, meaning that residents may have more opportunities for social interaction. The origin of Yulin neighbourhood dates back to the 1970s-1980s, when the construction of building 
clusters started. The Community Residents Committee (CRC) was established in 2001 to govern neighbourhoods. Some sustainability challenges faced by Yulin were mentioned in the field interviews, including run-down cultural and sports facilities and medical care centres. It was revealed in a previous study that the number of migrants has recently increased in Yulin, causing problems related to social inclusion between local and nonlocal residents [82].

The Xingyue neighbourhood is a suburban neighbourhood next to a logistic industry park outside the third ring road, which differs from the other two in the downtown area. It covers 39 hectares and accommodates over 3000 inhabitants. In spite of its remote location, the Xingyue neighbourhood still provides amenities for its inhabitants. Kiosks, a centre for the elderly, fitness courts, chess-playing rooms, barber shops, etc., are located within the living area. Outside the living area, a wide range of shops and services, including medical facilities, restaurants, banks, Internet cafés, and kindergartens, are provided on two $400 \mathrm{~m}$ long shopping streets, in addition to living areas that are highly accessible to residents. Xingyue is a typical resettlement neighbourhood built for accommodation of relocated residents during urban renewal. Prior to the urban renewal project, there were three villages located within the current studied area: Wuduolian, Yue'er, and Sisheng. At that time, the total area of the three villages was 3.1 square $\mathrm{km}$. The total number of affected residents was approximately 5000. Most of them chose to stay and resettle in the newly built Xingyue neighbourhood in different phases. Phase 1 started in 2011, Phase 2 started in 2012, and Phase 3 started in 2014.

The Jinyang neighbourhood is a typical high-density commodity-housing neighbourhood located in western Chengdu along Jinyang Avenue between the second and third ring roads. A total of 9794 inhabitants are accommodated within the 26 hectares of Jinyang neighbourhood. The diverse ground-floor space provides a wide range of facilities and services. It was one of the earliest projects developed by private property developers in Chengdu. In particular, Jinyang is a gated community built after 2000, which is different from the other two cases. The four main housing estates within the selected neighbourhood area are Club Garden (built 2002), Jinlan Yuan (built 2015), Ruitai Jincheng (built 2007), and Xijun Xianglin (built 2006). A decline in neighbourhood intimacy in the modern commodity-housing estates in China was stated in previous research [72].

\subsection{Questionnaire Design and Data Collection}

Surveys are one of the common methods to acquire a representative sample of the study area and a very good approach to examining a far larger number of factors than can be considered with empirical approaches (Czaja and Blair, 1996; Galliers, 1992). Thus, a questionnaire survey was adopted to measure and assess residents' perceptions of the selected elements of different neighbourhoods. The formulations of the questions were based on a theoretical framework (Table A1), which was developed through a comprehensive literature review of academic research and widely used sustainability assessment tools, including LEED (-ND), BREEAM (Communities), TAHER, CASBEE (-UD), DGNB (-NSQ), and Beam Plus ND. Thus, the answers to these questions represent the residents' perceptions of the different sustainability-related factors. In this study, these perceptions were called sustainability performance, and they were measured using the 5 point Likert-scale. The large number of factors selected from the literature were further reduced, and those that met the following four criteria were eliminated or combined with others:

- Mentioned in fewer than three references (either academic or industrial);

- The setting of the criteria does not fit the research objective of this study;

- The application scenario does not match the scale and profile of neighbourhoods in China;

- Overlapping with others.

Finally, 49 questions, including 33 questions designed based on lists of sub-factors in Table A1, were prepared to elicit the opinions of selected neighbourhood residents on their degree of agreement with the corresponding elements. The first chapter of the survey asks for the residents' perceptions of the sustainability performance and related attitudinal and frequency issues. It consists of six parts, including social support and safety, 
cultural identification and sense of belonging, economic activities, transport and energy environment, ecological and physical environment, and institution of neighbourhood governance. There are five to nine questions in each part, which specifically ask the respondent's degree of agreement with the statement concerning neighbourhoods elements related to a selected sustainability factor. For example, the first question is 'The housing price or monthly rent is affordable to me', which refers to the 'affordable housing' factor of social sustainability. The second chapter of the questionnaire asks about sociodemographic characteristics, including gender, age, property owner or tenant, Hukou status, duration of residence, education level, monthly income and expenditure, and overall satisfaction with the neighbourhood. After initially formulating the questions, eight experts with various specializations in neighbourhood planning and governance were invited to validate and improve the representation, clarity, and relevance of the questions in the survey.

For the sampling of respondents, stratified random sampling was adopted as a sampling method, given the essence of this study and the advantages of this method. Stratified random sampling refers to first selecting a specific group of the target population and then conducting the random sampling method. The main advantage of stratified sampling is that it captures key population characteristics in the sample. To collect valid information for the study, only approached respondents who were over 18 years old and permanent residents qualified to receive the questionnaire survey.

Finally, a total of 510 questionnaires were distributed through on-site, face-to-face interviews within the Yulin (170), Xingyue (170) and Jinyang (170) neighbourhoods in Chengdu between April and September 2017. According to Kotrlik and Higgins, a sampling size of 119 to 209 should be adequate for a survey study with a total population size of 4000 to 10,000 [83]. Thus, 170 was set as the number of collected samples in each neighbourhood. Ten trained research assistants conducted the interviews and recorded respondents' answers. The questionnaire surveys were conducted in sequential order: Xingyue in April 2017, and Yulin and Jinyang in September 2017. Each interview took roughly $20 \mathrm{~min}$, including briefing respondents on the research background and recording their evaluation. The interviewees were fully respected in terms of personal willingness and privacy. Completed surveys with any item missing were considered invalid and removed from the final data set [84].

The interviewers consisted of research assistants, who were divided into three groups to approach random people within the neighbourhoods. The questionnaire surveys were also conducted at a random time of day.

\subsection{Data and Model Analysis}

To explicitly interpret the tendencies of the overall results of the respondents' perceptions of the neighbourhood factors, the dichotomous split of self-stated agreement was adopted [49] in the descriptive analysis. Dichotomization of the Likert scale has previously been used in other research to simplify the scale. For example, Jeong and Lee found that dichotomous scales performed well compared to the current 5 point scale in safety attitudes questionnaire [85]. Ansell et al. transformed the 1-5-response scale used in relation to survey measures into a dichotomous scale (1-3 as 0 and $4-5$ as 1$)$ in governance research [86]. Accordingly, respondents who indicated that they agreed or strongly agreed were combined and split from the others in the statistics. In this research, 'the agreement rate' was used as an abbreviation of 'the proportion of respondents who indicated agree or strongly agree'.

The flow of data analysis and the modelling process are shown in Figure 4. IBM SPSS Statistics 19 was used for analysis. Cronbach's alpha $(\alpha)$ was used to indicate the average correlation or internal consistency of the collected data. Normally, the larger the $\alpha$, the higher the reliability of the collected data. One-way analysis of variance (ANOVA) was used to determine whether there were any statistically significant differences among the means of three or more independent (unrelated) groups. Given the relatively large sampling size (510) and variable numbers (33), Pearson's chi-square test was performed to 
exclude independent variables that were not significantly associated with the dependent variables $(Y)$ in order to reduce the interference factors. The significance cut-off level was set at 0.05 . Then, the remaining variables, socioeconomic characteristics, and dependent variables were included in the subsequent logistic regression.

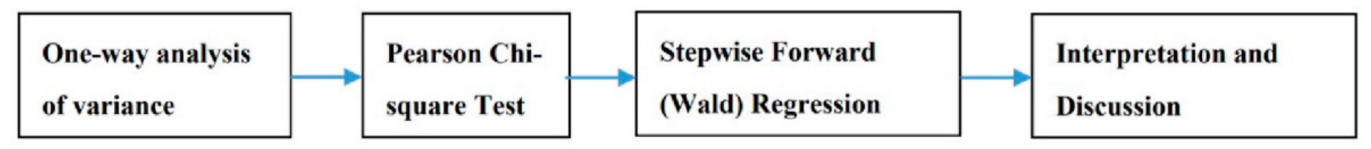

Figure 4. The flow of data analysis and modelling process.

Logistic regression modelling was employed to investigate significant associations among residents' perceptions of sustainability performance and neighbourhood satisfaction level, as well as moving intention. Unlike ordinary linear regression, logistic regression does not assume that the relationship between the independent variables and the dependent variable is linear. In the logistic regression analysis, stepwise logistical regression was adopted to explore the associations between sustainability and liveability factors, as well as moving intention. Compared with other regression models, stepwise regression is a semiautomated tool for building a model by fitting regression models in which the choice of predictive variables is determined by automatic procedures $[87,88]$. The process systematically adds the most significant variable or removes the least significant variable in each step. The use of stepwise regression for neighbourhood analysis has been validated other studies [89-91].

First, dependent variables measured at the five-scale level were dichotomised, while the independent variables remained at the five-scale level. Independent variables included in all initial backward conditional regression models also represented a range of socioeconomic factors. These factors include length of residence, education level, gender, Hukou status, and monthly income, which were controlled variables.

Then, based on the dichotomised variables, the binary logistic regression model (equation below) was used to estimate how the predictor variables (sustainability factors) were associated with the response variables (neighbourhood satisfaction level) and intention of moving out. Using the Hosmer and Lemeshow test, the goodness of fit was evaluated, while the overall percentage was used to evaluate the percentage of correct prediction by the model.

$$
\operatorname{Logit}(P)=\ln P(Y=1) / P(Y=0)=\beta_{0}+\beta_{1} X_{1}+\beta_{2} X_{2}+\cdots+\beta_{m} X_{m}
$$

where $P(Y \leq j)$ or $P(Y=1)$ is the probability of the event, $\beta_{0}$ is the constant $(0$ represents not satisfactory and 1 represents satisfactory), $\mathrm{Y}$ is the response variable, $\mathrm{x}_{\mathrm{m}}$ is the predictor variable, and $\beta_{\mathrm{m}}$ is the coefficient of the predictor variable.

Two models were applied. In Model 1, neighbourhood satisfaction was the dependent $(Y)=(1,0)$ variable within which 5 ordinal levels were dichotomized. For neighbourhood satisfaction, 'agree' (4) and 'strongly agree' (5) were attributed to $\mathrm{Y}=1$, while 'strongly disagree' (1), 'disagree' (2), and 'neutral' (3) were attributed to $Y=0$. The sustainability factors and socioeconomic characteristics were the independent variables.

In Model 2, moving intention was the dependent $(Y)=(1,0)$ variable. The sustainability factors, overall satisfaction with the neighbourhood and the socioeconomic characteristics were the independent variables.

\section{Results and Discussions}

A total of 170 samples was distributed and completed in each neighbourhood. The number of valid questionnaires from each neighbourhood was 160 (Yulin), 160 (Xingyue), and 162 (Jinyang). By dividing each by 170, the valid rate of the questionnaire survey is $94.1 \%, 94.1 \%$ and $95.3 \%$, respectively. Part of the data was compared with the sustainability performance results of the authors' previous paper [39], which was generated from the 
same project. This is briefly shown below in 4.1 as an important foundation for analysing the key results shown in 4.2 .

\subsection{Respondent Profile, Summary of Descriptive Statistics and Significance Test}

The socioeconomic characteristics, 'overall satisfaction with neighbourhood', and 'intention to stay living here or not' of the respondents in three neighbourhoods are displayed in Table 2. Yulin has the most respondents who have lived in the studied neighbourhood for longer than 10 years. This is to be expected, as Yulin is a traditional danwei neighbourhood that has not experienced large-scale urban renewal, and the social network there is relatively stable. Xingyue has the most respondents whose individual monthly income is lower than RMB 2000, which implies the large number of low-income inhabitants accommodated in suburban resettled neighbourhoods. It also has the most respondents who have commuting times above $30 \mathrm{~min}$. This also determined that the resettled residents do not have adequate public transport in their daily routines. Jinyang has the most youngsters, property owners, and new inhabitants, as well as highly educated individuals and those with a high monthly income and expenditure. Table 2 shows that Xingyue has the highest proportion of respondents who are satisfied with their neighbourhood. In comparison, Jinyang has the lowest figure. This also indicates the largest proportion of respondents who wish to move out of Jinyang and the smallest proportion in Xingyue.

Table 2. Socioeconomic profiles of the three neighbourhoods.

\begin{tabular}{|c|c|c|c|}
\hline & Yulin & Xingyue & Jinyang \\
\hline $\begin{array}{l}\text { No. of valid } \\
\text { responses }\end{array}$ & $\begin{array}{c}160 \\
(10 \text { invalid })\end{array}$ & $\begin{array}{c}160 \\
(10 \text { invalid })\end{array}$ & $\begin{array}{c}162 \\
\text { (8 invalid) }\end{array}$ \\
\hline \multicolumn{4}{|c|}{ Gender } \\
\hline Male & $72(45 \%)$ & $64(40 \%)$ & $78(48.1 \%)$ \\
\hline Female & $88(55 \%)$ & $96(60 \%)$ & $84(51.9 \%)$ \\
\hline \multicolumn{4}{|c|}{ Age Group } \\
\hline $18-35$ & $46(28.7 \%)$ & $48(30.0 \%)$ & $72(44.4 \%)$ \\
\hline $36-50$ & $41(25.6 \%)$ & $50(31.3 \%)$ & $46(28.4 \%)$ \\
\hline $51-65$ & $38(23.8 \%)$ & $44(27.5 \%)$ & $32(19.8 \%)$ \\
\hline $66-80$ & $27(16.9 \%)$ & $18(11.25 \%)$ & $10(6.2 \%)$ \\
\hline 80 or above & $8(5.0 \%)$ & $0(0 \%)$ & $2(1.2 \%)$ \\
\hline \multicolumn{4}{|c|}{ Status of residence } \\
\hline Owner & $88(52.5 \%)$ & $93(58.1 \%)$ & $113(69.8 \%)$ \\
\hline tenant & $72(47.5 \%)$ & $67(41.9 \%)$ & $49(30.2 \%)$ \\
\hline \multicolumn{4}{|c|}{ Hukou type } \\
\hline Local & $84(52.5 \%)$ & $95(59.4 \%)$ & $91(56.2 \%)$ \\
\hline Nonlocal & $76(47.5 \%)$ & $64(40 \%)$ & $71(43.8 \%)$ \\
\hline Missing response & & 1 & \\
\hline \multicolumn{4}{|c|}{ Duration of residence } \\
\hline Less than 1 year & $23(14.4 \%)$ & $24(15.0 \%)$ & $38(23.5 \%)$ \\
\hline 1 to 3 years & $28(17.5 \%)$ & $35(21.9 \%)$ & $46(28.4 \%)$ \\
\hline 4 to 6 years & $20(12.5 \%)$ & $44(27.5 \%)$ & $25(15.4 \%)$ \\
\hline 7 to 10 years & $17(10.6 \%)$ & $47(29.4 \%)$ & $24(14.8 \%)$ \\
\hline Longer than 10 years & $72(45 \%)$ & $10(6.3 \%)$ & $29(17.9 \%)$ \\
\hline
\end{tabular}


Table 2. Cont.

\begin{tabular}{|c|c|c|c|}
\hline & Yulin & Xingyue & Jinyang \\
\hline \multicolumn{4}{|c|}{ Education } \\
\hline $\begin{array}{c}\text { Lower than primary } \\
\text { school }\end{array}$ & $13(8.1 \%)$ & $32(20.0 \%)$ & $8(4.9 \%)$ \\
\hline Elementary school & $42(26.3 \%)$ & $23(14.4 \%)$ & $15(9.3 \%)$ \\
\hline Secondary school & $56(35 \%)$ & $61(38.1 \%)$ & $39(24.1 \%)$ \\
\hline College or above & $49(30.6 \%)$ & $44(27.5 \%)$ & $100(61.7 \%)$ \\
\hline \multicolumn{4}{|c|}{ Monthly Income } \\
\hline 2000 or below & $50(31.3 \%)$ & 75 (46.9\%) & $24(14.8 \%)$ \\
\hline 2000 to 4000 & $73(45.6 \%)$ & $51(31.9 \%)$ & $39(24.1 \%)$ \\
\hline 4000 to 6000 & $23(14.4 \%)$ & $24(15.0 \%)$ & $46(28.4 \%)$ \\
\hline 6000 to 8000 & $11(6.9 \%)$ & $9(5.6 \%)$ & $25(15.4 \%)$ \\
\hline 8000 or above & $3(1.9 \%)$ & $1(0.6 \%)$ & $28(17.3 \%)$ \\
\hline \multicolumn{4}{|c|}{ Family monthly expenditure } \\
\hline 3000 or below & $85(53.1 \%)$ & $94(58.8 \%)$ & $41(25.3 \%)$ \\
\hline 3000 to 5000 & $48(30 \%)$ & $43(26.9 \%)$ & $42(25.9 \%)$ \\
\hline 5000 to 7000 & $13(8.1 \%)$ & $20(12.5 \%)$ & $38(23.5 \%)$ \\
\hline 7000 to 9000 & $7(4.4 \%)$ & $1(0.6 \%)$ & $16(9.9 \%)$ \\
\hline 9000 above & $7(4.4 \%)$ & $2(1.3 \%)$ & $25(15.4 \%)$ \\
\hline \multicolumn{4}{|c|}{ Commuting time of Job to Housing } \\
\hline Less than 5 min & $32(20.5 \%)$ & $10(6.8 \%)$ & $20(12.4 \%)$ \\
\hline 5 to $15 \mathrm{~min}$ & $39(25.0 \%)$ & $32(21.8 \%)$ & $51(31.7 \%)$ \\
\hline 15 to $30 \mathrm{~min}$ & $43(27.6 \%)$ & $53(36.1 \%)$ & $51(31.7 \%)$ \\
\hline $30 \mathrm{~min}$ to $1 \mathrm{~h}$ & $34(21.8 \%)$ & $33(22.4 \%)$ & $27(16.8 \%)$ \\
\hline Longer than $1 \mathrm{~h}$ & $8(5.1 \%)$ & $19(12.9 \%)$ & $12(7.4 \%)$ \\
\hline Invalid response & 4 & 13 & 1 \\
\hline \multicolumn{4}{|c|}{ Commuting time between home and transport station } \\
\hline Less than 3 min & $33(20.6 \%)$ & $42(26.3 \%)$ & $30(18.7 \%)$ \\
\hline 4 to $10 \mathrm{~min}$ & $88(55.0 \%)$ & $68(42.5 \%)$ & $111(69.4 \%)$ \\
\hline 11 to $20 \mathrm{~min}$ & $27(16.9 \%)$ & $33(20.6 \%)$ & $15(9.4 \%)$ \\
\hline Longer than $20 \mathrm{~min}$ & $12(7.5 \%)$ & $17(10.6 \%)$ & $4(2.5 \%)$ \\
\hline \multicolumn{4}{|c|}{ Intention to stay living here or not } \\
\hline Yes & $130(81.3 \%)$ & $135(84.4 \%)$ & $110(67.9 \%)$ \\
\hline No & $30(18.8 \%)$ & $25(15.6 \%)$ & $52(32.1 \%)$ \\
\hline \multicolumn{4}{|c|}{ Overall neighbourhood satisfaction } \\
\hline Less than satisfied & $71(44.4 \%)$ & $62(38.8 \%)$ & $98(60.5 \%)$ \\
\hline Satisfied & $89(55.6 \%)$ & $98(61.3 \%)$ & $64(39.5 \%)$ \\
\hline
\end{tabular}

Table 3 shows respondents' perceptions of the sustainability performances and overall satisfaction of the three neighbourhoods. It also includes factors where significant variations were found among the three. The result shows there is a significant difference among the three neighbourhoods. Xingyue had the highest mean value (3.67) of overall satisfaction and the highest proportion of agreement rate $(61.3 \%)$, while Jinyang had the lowest mean value (3.31) of overall satisfaction and the lowest proportion of agreement rate (39.5\%). 
Yulin's performance is in between these two. The difference is significant at the 0.05 level, which suggests different levels of quality of life in these three transitional neighbourhoods.

Table 3. Satisfaction rates of the respondents for different sustainability factors in each neighbourhood.

\begin{tabular}{|c|c|c|c|c|c|}
\hline \multicolumn{2}{|c|}{ Sustainability Performance } & Yulin (1) & Xingyue (2) & Jinyang (3) & ANOVA (Sig) \\
\hline \multicolumn{2}{|c|}{ Number of Valid Surveys } & $\mathrm{N}=160$ & $\mathrm{~N}=160$ & $\mathrm{~N}=162$ & \\
\hline \multicolumn{6}{|c|}{ Social Factors } \\
\hline $\begin{array}{l}\text { Accessible and convenient } \\
\text { amenities }\end{array}$ & $\begin{array}{c}\text { Good performance in all } 3 \\
\text { (percent }>85 \% \text { and mean } \\
\text { value }>4 \text { ) }\end{array}$ & $\begin{array}{l}91.3 \% \\
(4.17)\end{array}$ & $\begin{array}{l}86.3 \% \\
(4.01)\end{array}$ & $\begin{array}{l}91.4 \% \\
(4.36)\end{array}$ & $\begin{array}{c}F=7.535 \\
(0.001)\end{array}$ \\
\hline $\begin{array}{l}\text { Often participating in } \\
\text { collective activities }\end{array}$ & $\begin{array}{c}\text { Poor performance in all } 3 \\
\text { (percent }<45 \% \text { and mean } \\
\text { value }<3 \text { ) }\end{array}$ & $\begin{array}{l}25.6 \% \\
(2.52)\end{array}$ & $\begin{array}{l}33.8 \% \\
(2.68)\end{array}$ & $\begin{array}{l}18.5 \% \\
(2.35)\end{array}$ & $\begin{array}{c}F=2.794 \\
(0.062)\end{array}$ \\
\hline $\begin{array}{l}\text { Opportunity to have social } \\
\text { interaction within and } \\
\text { without neighbourhoods }\end{array}$ & \multirow{2}{*}{$\begin{array}{l}\text { Variation in performance }> \\
0.4 \text { or percent difference } \\
>20 \% \text { (between any two) }\end{array}$} & $\begin{array}{l}54.4 \% \\
(3.30)\end{array}$ & $\begin{array}{l}75 \% \\
(3.76)\end{array}$ & $\begin{array}{l}52.5 \% \\
(3.27)\end{array}$ & $\begin{array}{l}F=9.000 \\
(0.000)\end{array}$ \\
\hline $\begin{array}{l}\text { Preference of the collective } \\
\text { living pattern }\end{array}$ & & $\begin{array}{l}68.6 \% \\
(3.77)\end{array}$ & $\begin{array}{l}78.1 \% \\
(4.06)\end{array}$ & $\begin{array}{l}55.0 \% \\
(3.54)\end{array}$ & $\begin{array}{l}F=10.282 \\
\quad(0.000)\end{array}$ \\
\hline \multicolumn{6}{|c|}{ Economic Factors } \\
\hline $\begin{array}{l}\text { Accessible grocery } \\
\text { shopping and other } \\
\text { consumption spaces near } \\
\text { the neighbourhood }\end{array}$ & $\begin{array}{c}\text { Good performance in all } 3 \\
\text { (percent }>85 \% \text { and mean } \\
\text { value }>4)\end{array}$ & $\begin{array}{l}97.5 \% \\
(4.49)\end{array}$ & $\begin{array}{l}99.4 \% \\
(4.69)\end{array}$ & $\begin{array}{l}93.2 \% \\
(4.42)\end{array}$ & $\begin{array}{c}F=9.346 \\
(0.000)\end{array}$ \\
\hline $\begin{array}{l}\text { Attending economic } \\
\text { activities within the } \\
\text { neighbourhood. }\end{array}$ & $\begin{array}{c}\text { Poor performance in all } 3 \\
\text { (percent }<45 \% \text { and mean } \\
\text { value }<3 \text { ) }\end{array}$ & $\begin{array}{l}15.0 \% \\
(2.22)\end{array}$ & $\begin{array}{l}34.4 \% \\
(2.61)\end{array}$ & $\begin{array}{l}14.8 \% \\
(2.07)\end{array}$ & $\begin{array}{c}F=8.437 \\
(0.000)\end{array}$ \\
\hline $\begin{array}{l}\text { Satisfaction with public } \\
\text { methods of information }\end{array}$ & $\begin{array}{c}\text { Variation in } \\
\text { performance }>0.4 \text { or } \\
\text { percent difference }>20 \% \\
\text { (between any two) }\end{array}$ & $\begin{array}{l}38.8 \% \\
(3.19)\end{array}$ & $\begin{array}{l}69.4 \% \\
(3.64)\end{array}$ & $\begin{array}{l}43.4 \% \\
(3.22)\end{array}$ & $\begin{array}{l}F=10.397 \\
\quad(0.000)\end{array}$ \\
\hline \multicolumn{6}{|c|}{ Environmental Factors } \\
\hline $\begin{array}{l}\text { Acceptable distance to the } \\
\text { public transport station }\end{array}$ & $\begin{array}{c}\text { Good performance in all } 3 \\
\text { (percent }>85 \% \text { and mean } \\
\text { value }>4)\end{array}$ & $\begin{array}{l}95.0 \% \\
(4.33)\end{array}$ & $\begin{array}{l}89.4 \% \\
(4.01)\end{array}$ & $\begin{array}{l}89.5 \% \\
(4.30)\end{array}$ & $\begin{array}{c}F=8.713 \\
(0.000)\end{array}$ \\
\hline \multicolumn{6}{|c|}{ Institutional Factors } \\
\hline $\begin{array}{l}\text { Opportunities to attend } \\
\text { and express myself in the } \\
\text { neighbourhood } \\
\text { management meeting }\end{array}$ & $\begin{array}{c}\text { Poor performance in all } 3 \\
\text { (percent }<45 \% \text { and } \\
\text { value }<3 \text { ) }\end{array}$ & $\begin{array}{l}23.8 \% \\
(2.28)\end{array}$ & $\begin{array}{l}22.5 \% \\
(2.29)\end{array}$ & $\begin{array}{l}24.7 \% \\
(2.43)\end{array}$ & $\begin{array}{c}F=0.759 \\
(0.469)\end{array}$ \\
\hline $\begin{array}{l}\text { Benefits of engaging } \\
\text { external parties in } \\
\text { neighbourhood } \\
\text { development }\end{array}$ & $\begin{array}{c}\text { Good performance in all } 3 \\
\text { (percent }>85 \% \text { or mean } \\
\text { value }>4 \text { ) }\end{array}$ & $\begin{array}{l}88.1 \% \\
(3.45)\end{array}$ & $\begin{array}{l}90.0 \% \\
(3.57)\end{array}$ & $\begin{array}{l}90.7 \% \\
(3.39)\end{array}$ & $\begin{array}{c}F=1.536 \\
(0.216)\end{array}$ \\
\hline Overall satisfaction wi & th neighbourhood life & $\begin{array}{l}55.7 \% \\
(3.59)\end{array}$ & $\begin{array}{l}61.3 \% \\
(3.67)\end{array}$ & $\begin{array}{l}39.5 \% \\
(3.31)\end{array}$ & $\begin{array}{c}\mathrm{F}=10.731 \\
(0.000)\end{array}$ \\
\hline
\end{tabular}

There are some factors in which all three neighbourhoods performed very well (percent $>85 \%$; mean value $>4$ ). They include 'accessible and convenient amenities', 'accessible grocery shopping and other consumption space near the neighbourhood', 'acceptable distance to the public transport station', and 'benefits of engaging external parties in neighbourhood development'. This shows that all the neighbourhoods have good supportive facilities and services contributing to sustainability. In contrast, all three neigh- 
bourhoods performed relatively poorly in 'often participating in collective activities', 'attending economic activities within the neighbourhood' and 'opportunities to attend and express myself in the neighbourhood management meeting'. This reveals that the extent of public participation in various aspects is low, regardless of the neighbourhood context. For the factors in which significant variations were found among the three neighbourhoods, Xingyue's performance exceeded that of the other two in 'opportunity to have social interaction within and without neighbourhoods', 'preference of the collective living pattern' and 'satisfaction with public methods of information'. This surprising result indicates the possibility of retaining good social interaction and neighbourhood governance in a resettlement neighbourhood after resettling activities that were previously regarded as threats to social sustainability.

\subsection{Associations between Sustainability and Neighbourhood Satisfaction}

Model 1 specified the significant associations between residents' perceptions of specific factors (independent variables) and neighbourhood satisfaction (dependent variable) in three different neighbourhoods, as shown in Table 4 . There are variations in the range of significant sustainability factors affecting overall neighbourhood satisfaction among the three.

Table 4. Model 1 (including sustainability factors and neighbourhood satisfaction).

\begin{tabular}{|c|c|c|c|c|c|c|c|c|c|c|c|c|c|c|}
\hline \multicolumn{15}{|c|}{ Dependent Variable: Neighbourhood Satisfaction Degree $(Y, 0,1)$} \\
\hline \multicolumn{4}{|c|}{ Total } & \multicolumn{4}{|c|}{$\begin{array}{c}\text { Yulin } \\
\text { (Danwei) }\end{array}$} & \multicolumn{4}{|c|}{$\begin{array}{c}\text { Xinyue } \\
\text { (Resettlement) }\end{array}$} & \multicolumn{3}{|c|}{$\begin{array}{c}\text { Jinyang } \\
\text { (Commodity Housing) }\end{array}$} \\
\hline B & S.E. & Wald & Sig. & B & S.E. & Wald & Sig. & B & S.E. & Wald & Sig. & S.E. & Wald & Sig. \\
\hline \multicolumn{15}{|c|}{ Social elements (A and B) } \\
\hline \multicolumn{4}{|c|}{ Affordable house } & \multicolumn{4}{|c|}{ 1. Sense of security } & \multicolumn{4}{|c|}{ 1. Sense of security } & \multirow{4}{*}{\multicolumn{3}{|c|}{ None }} \\
\hline 0.249 & 0.107 & 5.421 & 0.020 & 0.794 & 0.292 & 7.392 & 0.007 & 0.638 & 0.208 & 9.381 & 0.002 & & & \\
\hline \multicolumn{4}{|c|}{ Sense of security } & \multicolumn{4}{|c|}{$\begin{array}{c}\text { 2. Preference of } \\
\text { neighbourhood's big family } \\
\text { vibe }\end{array}$} & \multicolumn{4}{|c|}{$\begin{array}{l}\text { 2. Regard myself as a member } \\
\text { of the neighbourhood }\end{array}$} & & & \\
\hline 0.373 & 0.116 & 10.346 & 0.001 & 0.538 & 0.244 & 4.844 & 0.028 & 0.583 & 0.190 & 9.376 & 0.002 & & & \\
\hline \multicolumn{15}{|c|}{ Economic elements (C) } \\
\hline \multicolumn{4}{|c|}{$\begin{array}{l}\text { Participation in economic } \\
\text { activities within the } \\
\text { neighbourhood }\end{array}$} & \multirow{2}{*}{\multicolumn{4}{|c|}{ None }} & \multirow{2}{*}{\multicolumn{4}{|c|}{ None }} & \multirow{2}{*}{\multicolumn{3}{|c|}{ None }} \\
\hline 0.226 & 0.089 & 6.429 & 0.011 & & & & & & & & & & & \\
\hline \multicolumn{15}{|c|}{ Environmental elements (D and E) } \\
\hline \multicolumn{4}{|c|}{$\begin{array}{l}\text { Night lighting within } \\
\text { neighbourhood }\end{array}$} & \multicolumn{4}{|c|}{ 3. Satisfactory fresh air } & \multicolumn{4}{|c|}{$\begin{array}{l}\text { 3. Night lighting within } \\
\text { neighbourhood }\end{array}$} & \multicolumn{3}{|c|}{$\begin{array}{l}\text { 1. Sense and habit of energy } \\
\text { saving }\end{array}$} \\
\hline 0.298 & 0.127 & 5.552 & 0.018 & 0.652 & 0.240 & 7.377 & 0.007 & 1.268 & 0.300 & 17.841 & 0.000 & -0.4200 .188 & 5.024 & 0.025 \\
\hline \multicolumn{4}{|c|}{$\begin{array}{l}\text { Clean internal roads and } \\
\text { adequate garbage bins }\end{array}$} & \multirow{2}{*}{\multicolumn{4}{|c|}{ None }} & \multirow{2}{*}{\multicolumn{4}{|c|}{ None }} & \multicolumn{3}{|c|}{$\begin{array}{l}\text { 2. Clean internal roads and } \\
\text { adequate garbage bins }\end{array}$} \\
\hline 0.409 & 0.141 & 8.418 & 0.004 & & & & & & & & & $0.681 \quad 0.259$ & 6.933 & 0.008 \\
\hline \multicolumn{15}{|c|}{ Institutional elements (F) } \\
\hline \multicolumn{4}{|c|}{ Responses from the CRC } & \multicolumn{4}{|c|}{$\begin{array}{l}\text { 4. Solution achieved by } \\
\text { informing the CRC of } \\
\text { problems }\end{array}$} & \multicolumn{4}{|c|}{$\begin{array}{l}\text { 4. Solution achieved by } \\
\text { informing the CRC of } \\
\text { problems }\end{array}$} & 3. Responses & rom th & CRC \\
\hline 0.360 & 0.106 & 11.472 & 0.001 & 0.706 & 0.204 & 11.932 & 0.001 & 0.685 & 0.247 & 7.701 & 0.006 & 0.487 & 6.802 & 0.009 \\
\hline & & & & $\begin{array}{r}5 . \text { A } \\
\text { prope } \\
\text { on }\end{array}$ & $\begin{array}{l}\text { ceptabl } \\
\text { ty man } \\
\text { ropert } \\
\text { ten }\end{array}$ & $\begin{array}{l}\text { variatio } \\
\text { gement } \\
\text { owner a } \\
\text { nts }\end{array}$ & $\begin{array}{l}\text { n of } \\
\text { policy } \\
\text { nd }\end{array}$ & & & & & $\begin{array}{r}\text { 4. Benefits } \\
\text { external } \\
\text { neighbourhoo }\end{array}$ & $\begin{array}{l}\text { f engag } \\
\text { arties i } \\
\text { develc }\end{array}$ & ment \\
\hline & & & & 0.658 & 0.226 & 8.468 & 0.004 & & & & & 0.738 & 9.024 & 0.003 \\
\hline
\end{tabular}


Table 4. Cont

\begin{tabular}{|c|c|c|c|c|c|c|c|c|c|c|c|c|c|c|c|}
\hline \multicolumn{16}{|c|}{ Dependent Variable: Neighbourhood Satisfaction Degree $(Y 0,1)$} \\
\hline \multicolumn{4}{|c|}{ Total } & \multicolumn{4}{|c|}{$\begin{array}{c}\text { Yulin } \\
\text { (Danwei) }\end{array}$} & \multicolumn{4}{|c|}{$\begin{array}{c}\text { Xinyue } \\
\text { (Resettlement) }\end{array}$} & \multicolumn{4}{|c|}{$\begin{array}{c}\text { Jinyang } \\
\text { (Commodity Housing) }\end{array}$} \\
\hline B & S.E. & Wald & Sig. & B & S.E. & Wald & Sig. & B & S.E. & Wald & Sig. & B & S.E. & Wald & Sig. \\
\hline \multicolumn{16}{|c|}{ Socioeconomic characteristics } \\
\hline \multicolumn{4}{|c|}{ Age } & \multicolumn{4}{|c|}{ Age } & & & & & \multicolumn{4}{|c|}{ Family monthly expenditure } \\
\hline 0.395 & 0.104 & 14.538 & 0.000 & 0.369 & 0.187 & 3.868 & 0.049 & & & & & 0.292 & 0.139 & 4.376 & 0.036 \\
\hline \multicolumn{16}{|c|}{$\begin{array}{l}\text { No significant results: } \\
\text { Gender; status of residence; local or nonlocal Hukou; duration of residence; education; monthly income }\end{array}$} \\
\hline \multicolumn{16}{|c|}{ Cronbach's Alpha } \\
\hline \multicolumn{4}{|c|}{0.810} & \multicolumn{4}{|c|}{0.799} & \multicolumn{4}{|c|}{0.835} & \multicolumn{4}{|c|}{0.817} \\
\hline
\end{tabular}

For Yulin (danwei), 55.6\% of respondents were satisfied with neighbourhood life. The range is relatively more diverse, since the five significant factors are from three different sustainability dimensions. As shown in Model 1, the five factors are 'sense of security', 'preference of neighbourhood's collective lifestyle', 'satisfactory fresh air', 'solution achieved by informing the CRC of problems' and 'acceptable variation of property management policy on property owner and tenants'. The wide range implies that the underlying determinants in Yulin are decentralized rather than centralized. First, the regression results show that 'sense of security' is significant. It can be partly associated with the small yard formation of each unit in Yulin, and its tested significance helps to understand how well the formation contributes to the perceived satisfaction of the residents. Second, 'preference of neighbourhood's collective lifestyle' is only significant in Yulin among the three. This can be attributed to the highest proportion of respondents (45\%) who had lived in their neighbourhood for longer than 10 years. This supports the findings of a previous study in China that length of residence is significantly associated with a stronger sense of belonging and community [92]. The more well-known neighbours the residents have, the more likely they are to prefer the existing social network, which improves their satisfaction level. Third, poor perceived air quality and its significant effect in the model suggest that improving the air quality of living environments should be a priority for improving neighbourhood satisfaction in Yulin. Fourth, 'solution achieved by informing the CRC of problems' indicates how the CRC's response to residents' requests is significantly associated with their satisfaction. Finally, 'acceptable variation of property management policy on property owner and tenants' is only significant in Yulin and can be interpreted by considering that Yulin has the largest proportion (47.5\%) of nonlocal Hukou holders among the three neighbourhoods. This suggests that a fair and reasonable property management policy is significant for building a satisfactory living environment in the danwei neighbourhood if tenants account for a significant number of residents.

For Xingyue (resettlement), $61.3 \%$ of respondents indicate that they are satisfied with the neighbourhood, which is the best performance among the three neighbourhoods. 'Sense of security', 'regard myself as a member of the neighbourhood', 'night lighting within neighbourhood' and 'solution achieved by informing the CRC of problems' are four significant factors from all sustainability dimensions. Two out of the four significant factors belong to the social dimension. This reveals that social sustainability significantly contributes to the perceived satisfaction in resettlement neighbourhoods. Specifically, sense of security and sense of belonging are the sub-factors. The dominant association between these social sustainability issues and satisfaction in urban renewal have been identified in previous studies [93-95]. Xingyue, as a resettlement neighbourhood, provides supporting evidence in the context of transitional China. The fact that 'night lighting within neighbourhood' is significant in the model shows that Xingyue has performed very well in providing satisfactory night lighting, as it has the highest mean value among the three neighbourhoods. This finding provides references for future studies, i.e., investigating how and to what 
extent night lighting affects satisfaction in terms of light density, lighting coverage, and duration of lighting. Similar to Yulin, 'solution achieved by informing the CRC of problems' highlights the significant part that the effectiveness of the CRC's responsive action plays in overall satisfaction. The fact that Xingyue illustrated the highest mean value of overall neighbourhood satisfaction among the three neighbourhoods prompts the need for further research into the associations among resettlement policy, social sustainability and overall satisfaction. Additionally, neighbourhood planning can be further advocated to foster both sustainability and liveability if a better understanding of the associations between them can be modelled to provide a useful reference for policy making.

For Jinyang (commodity), 39.5\% of respondents were satisfied with the neighbourhood, which is the poorest result among the three neighbourhoods. 'Sense and habit of energy saving', 'clean internal roads and adequate garbage bins', 'responses from the CRC' and 'benefits of engaging external parties in neighbourhood development' have significant effects on overall satisfaction. Unlike the other two neighbourhoods, Jinyang's significant factors are only confined to two dimensions: environmental and institutional. Social and economic dimensions do not have a significant association with neighbourhood satisfaction in commodity-housing neighbourhoods. In contrast, the few environmental and institutional factors indicated the significant role of environmental quality, neighbourhood service quality, and external party engagement in explaining the residents' overall neighbourhood satisfaction level. This was consistent with a previous study, which doubted the effect of neighbourly interaction on improving the residential satisfaction level in commodity-housing neighbourhoods [72]. Forrest and Kearns argued that residents 'buy into' a physically attractive neighbourhood without necessarily expecting interaction with their neighbours [96], while Plas and Lewis demonstrated that sometimes place attachment is related to the prestige of the area and not necessarily to social contacts [97]. This finding provides supportive evidence in China. Additionally, 'sense and habit of energy saving' is the only significant factor among all the factors that is negatively associated with neighbourhood satisfaction.

All four significant sustainability factors are from the environmental (two) and institutional dimensions (two) in the case of commodity housing (Jinyang). This result reveals that the associations between sustainability and liveability in commodity-housing neighbourhoods mainly concern environmental and institutional aspects. This should be particularly noted, given commodity housing will account for most of the newly built neighbourhoods as urbanization continues [98]. Interestingly, 'family monthly expenditure' is the only socioeconomic characteristic to have a significant positive effect on neighbourhood satisfaction in commodity-housing neighbourhoods. It demonstrates that the higher the monthly expenditure the family has, the higher the degree of satisfaction the resident has. This contradicts the argument proposed by Rojas that expenditure is an important explanatory variable for economic satisfaction but not for satisfaction and happiness [99]. The reason for this is partially that the property mortgage is the main housing expenditure in commodity housing (Jinyang), and it increases the financial threshold of meeting basic housing demand. It is more likely in a commodity-housing neighbourhood that residents bear an additional financial burden of a property mortgage; residents with a mortgage need a higher income to meet basic daily needs. Expenditure was regarded as the proxy of income in previous housing research [100]. The percentage of respondents whose family monthly expenditure is higher than RMB 5000 is $48.8 \%$ in Jinyang, $14.4 \%$ in Xingyue, and $16.9 \%$ in Yulin. The higher the expenditure a family has, the higher the income it will have and the higher the likelihood of other family needs being financially satisfied. Given the poor overall satisfaction performance of Jinyang, the exclusive role of family expenditure in indicating residential satisfaction in costly commodity-housing neighbourhoods was highlighted. Although higher expenditure is positively associated with satisfaction level, financial capability is not a dominant factor in determining residential satisfaction with the neighbourhood in commodity housing. 
As shown in Table 4, it can be seen that in addition to economic sustainability issues, a few sustainability factors are statistically associated with neighbourhood satisfaction in the three neighbourhoods in Chengdu. The economic sustainability dimension was found to be insignificant in all neighbourhoods. This can be supported by previous research findings that quality of life is determined by immediate and tangible conditions and interventions (i.e., here and now) [101]. Comparatively, these physical and close-to-life factors are more likely to be significantly associated with neighbourhood satisfaction. The results imply that social, environmental, and institutional endeavours to promote sustainability would be more effective in improving perceived levels of neighbourhood satisfaction.

\subsection{Associations between Sustainability and Moving Intention}

Model 2 (including sustainability factors and socioeconomic characteristics).

Table 5 shows the significant factors affecting moving intention in three different neighbourhoods. The significant factors vary in the three neighbourhoods, which indicates that there is a different mechanism affecting the latent population turnover of each type of neighbourhood.

Table 5. Model 2 (including sustainability factors and moving intention).

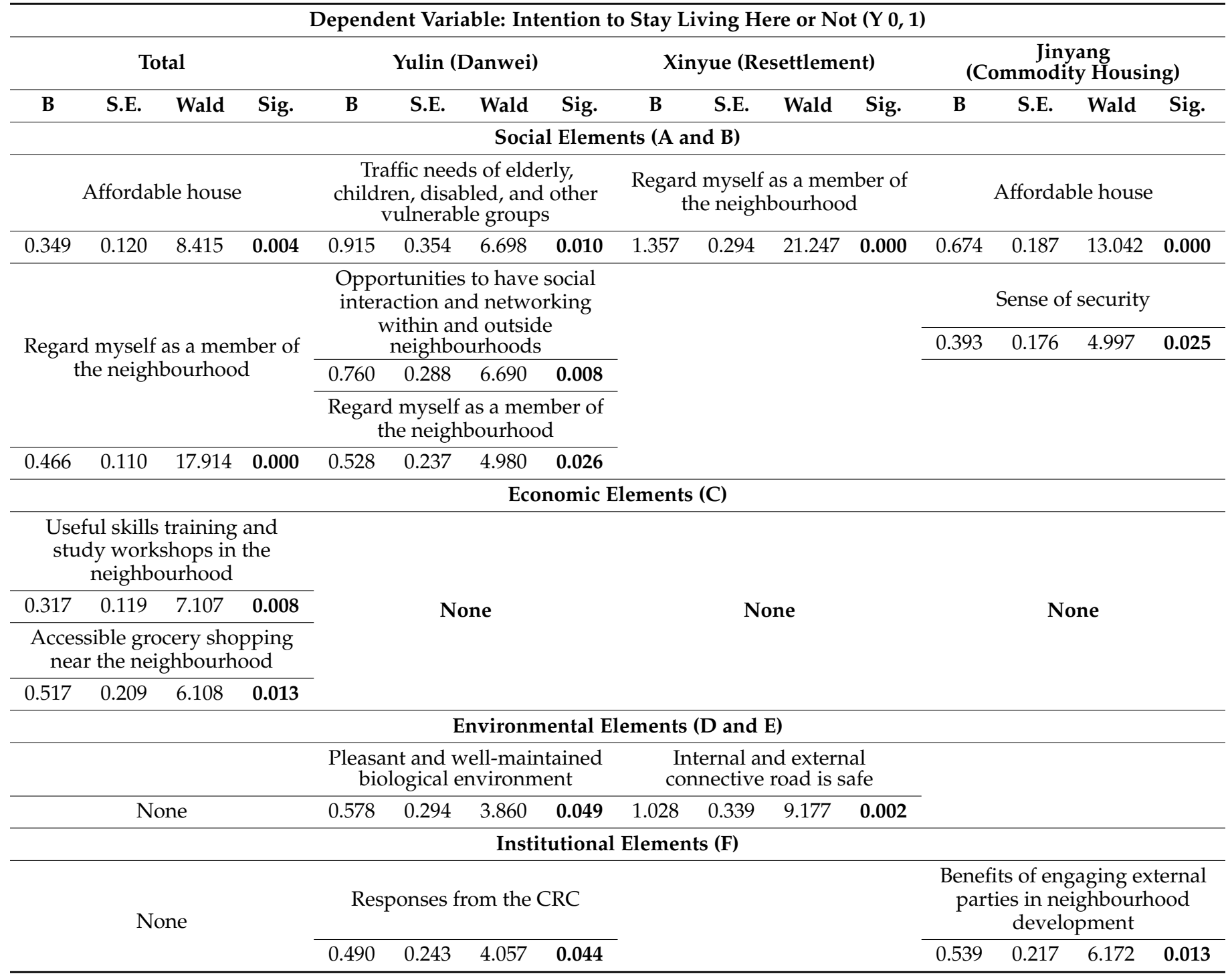


Table 5. Cont.

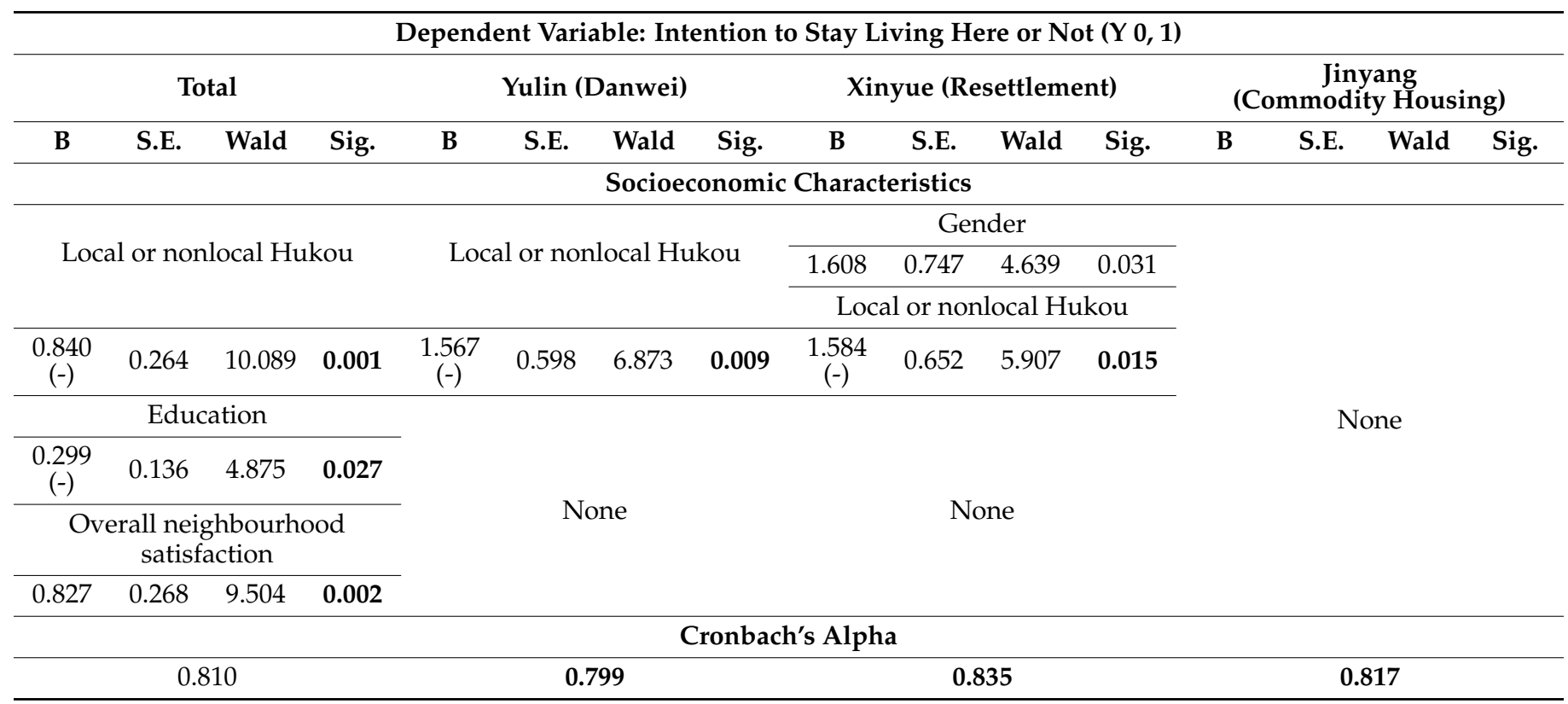

As stated, in Model 2, for Yulin (danwei), 81.3\% of the respondents indicated that they desired to continue living in the current neighbourhood. Similar to the results in the last section, the range of significant factors is also more diverse since the five factors are from three different dimensions: social, environmental, and institutional. These five factors are 'traffic needs of the elderly, children, disabled, and other vulnerable groups', 'opportunities to have social interaction and networking within and outside neighbourhoods', 'regard myself as a member of the neighbourhood', 'pleasant and well-maintained biological environment', and 'responses from the CRC'. These factors indicate that universal and equal traffic infrastructure, satisfactory social interaction, sense of belonging, natural environmental, and responsive neighbourhood services keep the residents living there. This result indicates that residential intention to stay living in the neighbourhood is affected by several diverse factors, rather than being dominated by one single factor.

For Xingyue (resettlement), $84.4 \%$ of the respondents indicated that they desired to stay living in the current neighbourhood. The two significant sustainable factors are 'regard myself as a member of the neighbourhood' and 'internal and external connective road is safe'. This demonstrates that sense of belonging and convenient and safe roads are significantly associated with people's intention to stay living in this resettlement neighbourhood.

For Jinyang (Commodity), $67.9 \%$ of the respondents indicate that they desire to remain living in the current neighbourhood. 'Affordable house', 'sense of security', and 'benefits of engaging external parties in neighbourhood development' are the specific significant factors spanning social and institutional aspects. Given Jinyang is a relatively new commodity-housing neighbourhood with better amenities, its average housing price is the highest among the three neighbourhoods. Thus, this suggests that whether the residents can afford their mortgage or rent affects their intention to stay, regardless of whether they are property owners or tenants. 'Sense of security' indicates the critical role played by security services provided by the neighbourhood to keep residents safe. 'Benefits of engaging external parties in neighbourhood development' refers to the sustainability factor 'community engagement in neighbourhood governance'. Its significance reveals that open and engaged neighbourhood governance plays a critical role in keeping the residents in the neighbourhood.

In comparison, different neighbourhoods have different significant factors, which evidences that the associations between sustainability and residential moving intention is contextual rather than universal. Most of the factors are exclusively significant in specific 
neighbourhoods, except two: 'regard myself as a member of the neighbourhood' and 'local or nonlocal Hukou', which are simultaneously significant in both Yulin and Xingyue. Given their longer history than that of Jinyang, this demonstrates that a sense of belonging is more likely to be significantly associated with residential intention to stay living in older neighbourhoods. Additionally, Hukou status is not significant in commodity-housing neighbourhoods, but it is significant in danwei and resettlement neighbourhoods. This demonstrates that whether residents have a local Hukou does not significantly affect their intention to stay living in a commodity-housing neighbourhood. Given the significance of 'affordable housing' in Jinyang, residents are more concerned about having a 'Hukou' in danwei and resettlement neighbourhoods and about the affordability of accommodation in commodity-housing neighbourhoods when they are considering remaining there or not.

Interestingly, no significant association between overall neighbourhood satisfaction and residential moving intention was found in either of these models. This can be further illustrated by the only two common significant factors between the two models. In other words, the associations of sustainability factors with satisfaction and moving intention are different and independent. Thus, there is no universal significant association between neighbourhood satisfaction and moving intention evidenced by this research. Surprisingly, this does not support the model developed by Marans and Rodgers and Campbell et al. [45,46], which defined the impact of neighbourhood satisfaction on moving intention. Thus, this implies the special context of neighbourhoods in China, which may be different from other contexts.

\section{Contextual Framework and Policy Implications}

Given that perceived sustainability and neighbourhood satisfaction were intercorrelated in a contextual way, the effects of sustainable neighbourhood development on residential neighbourhood satisfaction and moving intention varies with neighbourhood conditions. For policy implications, prioritizing the factors can provide a contextual solution to propose an action plan. Neighbourhood governors and planners should pay more attention to the significant factors that have poor performance. Yuan et al. stated that important but poor performance aspects should be priority issues to be addressed by neighbourhood planning [102].

Therefore, a contextual framework was proposed to develop adaptive sustainable neighbourhood planning, promoting sustainability and liveability simultaneously. First, Appendix A Table A2 further summarizes the common poor sustainability performances, respective different sustainable and socioeconomic threats, sustainability factors associated with residential satisfaction, and moving intention of the three neighbourhoods. The common poor sustainability performances include 'often participating in collective activities' (SC), 'occasionally visiting the neighbours' (SC), 'will attend the economic activities within the neighbourhood' (EC), and 'there is a chance to attend and express myself in the neighbourhood management meeting' (IN). This implies that there is an obvious shortcoming in public interaction and participation in neighbourhood life and governance, regardless of the contextual variations. In comparison, other socioeconomic and sustainable threats are relatively contextual. For instance, Yulin showed the highest heterogeneity and aging population. Xingyue was regarded as having the poorest commuting time of job to housing, worst sense of security, and unequal policy for different Hukou holders. Jinyang had the lowest collective interaction, lowest participation in economic activities, and highest moving-out intention. These common and different performances among three neighbourhoods provide references for differentiating the significant factors of each model.

Appendix A Table A3 shows the integrated contextual planning framework consisting of the key principles. The parameters of differentiation of the factors were proposed considering both the various performance and cross-factor associations to better integrate all the considerations. The framework was proposed by stratifying and ranking all the significant factors into three groups of principles: principles to be retained (A), principles to be enhanced (B), and principles to be urgently assured (C). Significant factors were included as (A) principles in the context of the corresponding neighbourhood if they had 
the best sustainability performance or lowest moving intention. Significant factors were included as (B) principles if they had moderate sustainability performance or moderate moving intention. Significant factors were included as (C) principles if they had the poorest sustainability performance or the highest moving intention.

Policy suggestions were proposed to address the three categories of principles in each neighbourhood context. For danwei neighbourhoods, first, priority should be given to optimizing the waste management mechanism to prevent trash accumulation, improving the effectiveness and promptness of addressing reported problems by residents, cultivating a sense of belonging by addressing the interests of nonlocal and tenant residents, and increasing the biodiversity of the ecological environment. The revealed top priorities are in line with those of a previous study that suggested that high-sensitivity facilities with poor performance should be improved first [103]. Second, the following improvement should be planned hereafter: organizing activities, such as gardening and dancing, to foster a vibrant and interactive collective lifestyle; issuing acceptable and equal property-management policies regarding both local and nonlocal residents; enhancing public participation in the policy-making process and the declaration of policy making, especially among nonlocals and tenants. Finally, small yard and entrance securities should be retained to make residents feel secure, particularly the aging and vulnerable population, and it should be ensured that adequate transport stations are allocated for public commuting demands, particularly for vulnerable groups [104].

For resettlement neighbourhoods, first, priority should be given to enhancing security, both access-control systems and staff, at entrances or exits, and guards should patrol within the neighbourhood; the interests and rights of nonlocal residents who do not have local Hukou should be preserved, including the visibility of policy declarations and clarification for all residents to prevent information asymmetry. Second, the following improvement should be planned hereafter: encouraging ex-residents to reunite with both familiar and new neighbours by organizing collective activities; providing accessible public transport and safe, convenient supporting facilities. Finally, the safety and walkability of the current internal and external connective roads should be ensured, and strict domestic and side parking should be issued. These results are partly consistent with a previous study on a resettlement neighbourhood in Suqian, China [105].

For commodity neighbourhoods, first, priority should be given to issuing strict sanitary policies, including clean roads, garbage-bin allocation, and waste management to improve the quality of the physical environment, engaging diverse external parties, such as social organizations and other enterprises, in neighbourhood development to create a more open and vibrant neighbourhood atmosphere, which will lead to higher residential satisfaction [106]. Second, the following improvements should be planned hereafter: securing residents' privacy and property interests by restricting the entry of strangers and optimizing guard patrols and establishing a property owners' committee to practice representative and statutory roles in regular governance. Allocating a display area (displays in common areas, such as the entrance lobbies, clubhouse lift lobbies, and inside lifts) for month-on-month and year-on-year energy use in the neighbourhood. Finally, neighbourhood-related charges, such as property management fees, parking charges, and even rentals, should be reviewed to provide economic and affordable housing.

This method of framework development can be utilized and applied in other areas where similar neighbourhood planning or policy making is anticipated. In this case study, the lowest number of A principles, poorest overall residential satisfaction degree, and highest moving-out intention in Jinyang revealed that the sustainability and liveability challenges in Jinyang are therefore relatively more severe and urgent than those in Yulin and Xingyue. This evidence shows that the commodity-housing neighbourhoods, which were built following higher urban planning standards and criteria, are not necessarily more sustainable or satisfactory from the residents' point of view [107]. Given commodity housing will account for most newly built neighbourhoods, planning should be reviewed from the perspective of the physical environment, service quality, and institutional mecha- 
nisms for balancing sustainability and liveability. For suggestions that can be delivered at the neighbourhood scale, the above policy and action plan can be used to determine a timetable for improvement. For problems relating to upper-level policies, this method can also provide empirical evidence as a reference for policy reviews. For instance, the results highlight the role of personal Hukou status in driving population turnover in danwei and resettlement neighbourhoods. Given its binary function in restricting urban and rural integration, as well as leading to uneven policies, as discussed in Section 2.4, Hukou policy reform to secure non-Hukou migrants should be advanced not only for better urban-rural integration but also to foster sustainable and liveable neighbourhoods.

A review of current neighbourhood planning guidelines to refine supplementary roles to other statutory planning in China, particularly in addressing nonphysical issues, should be conducted. For instance, according to the authors' interview with the project leader of the 'Chengdu Neighbourhood Development and Governance Planning 2018-2035', a top-down general neighbourhood planning guideline was issued to guide neighbourhood development. However, how the guideline addresses the different issues faced by more than 4000 neighbourhoods and the corresponding effective methods remains ambiguous. There are only general objectives, and the parameters are inadequate. An adaptive strategy is imperative for breaking the guidelines down into action plans considering the local context. In this sense, the proposed framework provides a general method for identifying the critical factors of corresponding neighbourhoods. It combines theoretical factors and local inputs by engaging neighbourhood members. This could supplement the general guidelines to enable the adoption of integrated top-down and bottom-up approaches for an adaptive solution in the specific context.

\section{Conclusions}

This paper provided an overview of the importance and complexity of the role of neighbourhood in advancing urban sustainability and liveability in the context of urban China. By reviewing neighbourhood development guided by the classic pattern, such as the principles of the neighbourhood unit concept [108] and pattern language [109], this study investigated the possible links between the classic pattern of development and the new paradigm of sustainability. The significance of residents' perceptions of neighbourhoods was underlined, given its effect on place recognition, attachment, and public action coordination with sustainability advocates. The findings suggest the existence of significant associations among a variety of neighbourhood sustainability factors and satisfaction from the perspective of users' perceptions. The findings also highlight the contextual variations among the significant factors set in different neighbourhoods. Generally, tangible or physical sustainability factors, such as keeping the neighbourhood environment clean and healthy, providing responsive property management services, building resource recycling and energy-efficiency systems, and engaging external parties, are more likely to contribute to improving neighbourhood satisfaction and suppressing moving intention. This evidences the higher degree of attractiveness of tangible and self-interest-related factors, out of all sustainability elements, to the public. For socioeconomic characteristics, only age and Hukou status were found to be associated with satisfaction levels and moving intention, respectively. This reveals that discrepancies might be attributed to the physical and institutional environment rather than respondents' background.

Given very few common associations and contexts were found among the three study neighbourhoods, this study calls for adaptive strategies of neighbourhood planning to further effectively enhance sustainability and liveability in Chengdu, China. For danwei and resettlement neighbourhoods, more comprehensive sustainable principles covering social, environmental, and institutional dimensions should be adopted. For commodity-housing neighbourhoods, environmental and institutional dimensions should be highlighted if neighbourhoods aim to satisfy more residents and suppress population turnover. No economic sustainability factor was found to be significant in this research, which reveals that there is no strong economic link between neighbourhood sustainability and liveability. 
Additionally, no significant association between satisfaction and moving intention was found in either of the individual neighbourhood scenarios. Therefore, their associations, as specified by Speare [59], are not supported by this empirical study in China. This suggests that the mechanisms affecting residential moving intentions are not dominated by the overall satisfaction level but rather by more complex and contextual factors.

While this study does not offer a conclusive answer to the question of how specific contextual factors affect neighbourhood sustainability performance, it does provide empirical research by identifying the factors that should be considered in different neighbourhoods to steer development towards being more sustainable and liveable. Generally, it is important to refer to universal sustainability principles commonly adopted in other countries, but it is equivalently imperative to implement the principles by proposing local strategies based on context and intrinsic problems. In this regard, human beings are the users of the neighbourhoods, and current sustainable development strategies have been constantly criticized for ignoring social considerations, especially human demands, and lacking forward thinking and action [103]. Thus, it is important to explore the links between neighbourhood sustainability and liveability within local contexts. To this end, the study provides a method for integrating top-down guidelines and local context in the process of framing sustainable neighbourhood planning. The new urban agenda and sustainable development goals offer constructive guidance for the planning strategies implemented by practitioners, urban planners, city and local leaders, and other policy makers who seek to meet the aspirations of their citizens while increasing the sustainability and liveability of their cities. The authors advocate for similar empirical studies in other contexts. This also suggests the need for future studies specifying the path of factor association by using structural equation modelling to deepen the understanding of these crucial associations at the neighbourhood scale.

Author Contributions: Conceptualization, Q.Z. and E.H.-K.Y.; data curation, Q.Z.; formal analysis, Q.Z.; funding acquisition, E.H.-K.Y. and E.H.-W.C.; investigation, Q.Z.; methodology, Q.Z. and E.H.-K.Y.; project administration, E.H.-K.Y. and E.H.-W.C.; resources, Q.Z.; supervision, E.H.-W.C.; validation, Q.Z.; writing—original draft, Q.Z.; writing—review and editing, E.H.-K.Y. and E.H.-W.C. All authors have read and agreed to the published version of the manuscript.

Funding: This study was supported by research grants provided by the Hong Kong Polytechnic University, Wuhan Land Use and Urban Spatial Planning Research Center, and Hubei Post-doc Innovation and Application Funding.

Institutional Review Board Statement: The study was conducted according to the guidelines of the Declaration of Helsinki, and approved by the Institutional Review Board of the Hong Kong Polytechnic University.

Informed Consent Statement: Informed consent was obtained from all subjects involved in the study.

Data Availability Statement: Some or all data, models, or codes that support the findings of this study are available from the corresponding author upon reasonable request.

Acknowledgments: The authors gratefully acknowledge all those who contributed to the interviews and questionnaire surveys.

Conflicts of Interest: The authors declare no conflict of interest.

\section{Appendix A}


Table A1. Theoretical framework of neighbourhood sustainability factors adopted in this study.

\begin{tabular}{|c|c|c|c|}
\hline \multirow[b]{2}{*}{ Neighbourhood Sustainability Elements } & \multirow[b]{2}{*}{ Factors } & \multicolumn{2}{|c|}{ References } \\
\hline & & Academic & Industrial \\
\hline \multirow{9}{*}{$\begin{array}{l}\text { Social } \\
\text { elements }\end{array}$} & Affordable and diverse provision of housing & {$[31,33,110]$} & [111-113] \\
\hline & $\begin{array}{l}\text { Delivery of services, provision of facilities and } \\
\text { amenities and their convenience }\end{array}$ & {$[31,93,114,115]$} & {$[111,112,116]$} \\
\hline & Cultural events and festivals & {$[117,118]$} & [119] \\
\hline & Building security & {$[120-122]$} & [119] \\
\hline & Demographic needs and priorities & {$[115,123,124]$} & [112] \\
\hline & $\begin{array}{l}\text { Surroundings, internal connectivity, and } \\
\text { inclusive access }\end{array}$ & {$[110,125-130]$} & {$[113,116]$} \\
\hline & Social interaction and functional mixing & {$[31,131,132]$} & {$[111,116]$} \\
\hline & Sense of belonging & {$[133,134]$} & [111] \\
\hline & Universal access & {$[125,126,135]$} & {$[111,113]$} \\
\hline \multirow{5}{*}{$\begin{array}{l}\text { Economic } \\
\text { elements }\end{array}$} & Cooperative activities & {$[33,136]$} & [119] \\
\hline & Information-service performance & {$[137,138]$} & {$[116,119]$} \\
\hline & Local training and skills & {$[115,139]$} & [112] \\
\hline & Housing and job proximity & {$[115,140]$} & [113] \\
\hline & Accessible trade market & [141] & [111] \\
\hline \multirow{10}{*}{ Environmental elements } & Multiple types of transit & [31] & {$[111-113,116,119]$} \\
\hline & Light and dust pollution & [142] & {$[112,113,143]$} \\
\hline & Access to public transport & {$[31,115,125,126]$} & {$[112,113,116]$} \\
\hline & Public transport facilities & {$[115,144,145]$} & {$[112,113,116,143]$} \\
\hline & $\begin{array}{l}\text { Resource Cycling and water-circulation } \\
\text { system and reused infrastructure }\end{array}$ & {$[115,146]$} & {$[113,116,119,143]$} \\
\hline & Outdoor air quality & {$[35]$} & {$[111,112,143]$} \\
\hline & Ecological and biodiversity & [147] & {$[111,112,119,143]$} \\
\hline & Quality of open space & {$[33,115]$} & {$[111,112,116]$} \\
\hline & Outdoor thermal environment & [148] & [111-113] \\
\hline & Noise & {$[36,38,149,150]$} & {$[111,112,116,143]$} \\
\hline
\end{tabular}


Table A1. Cont.

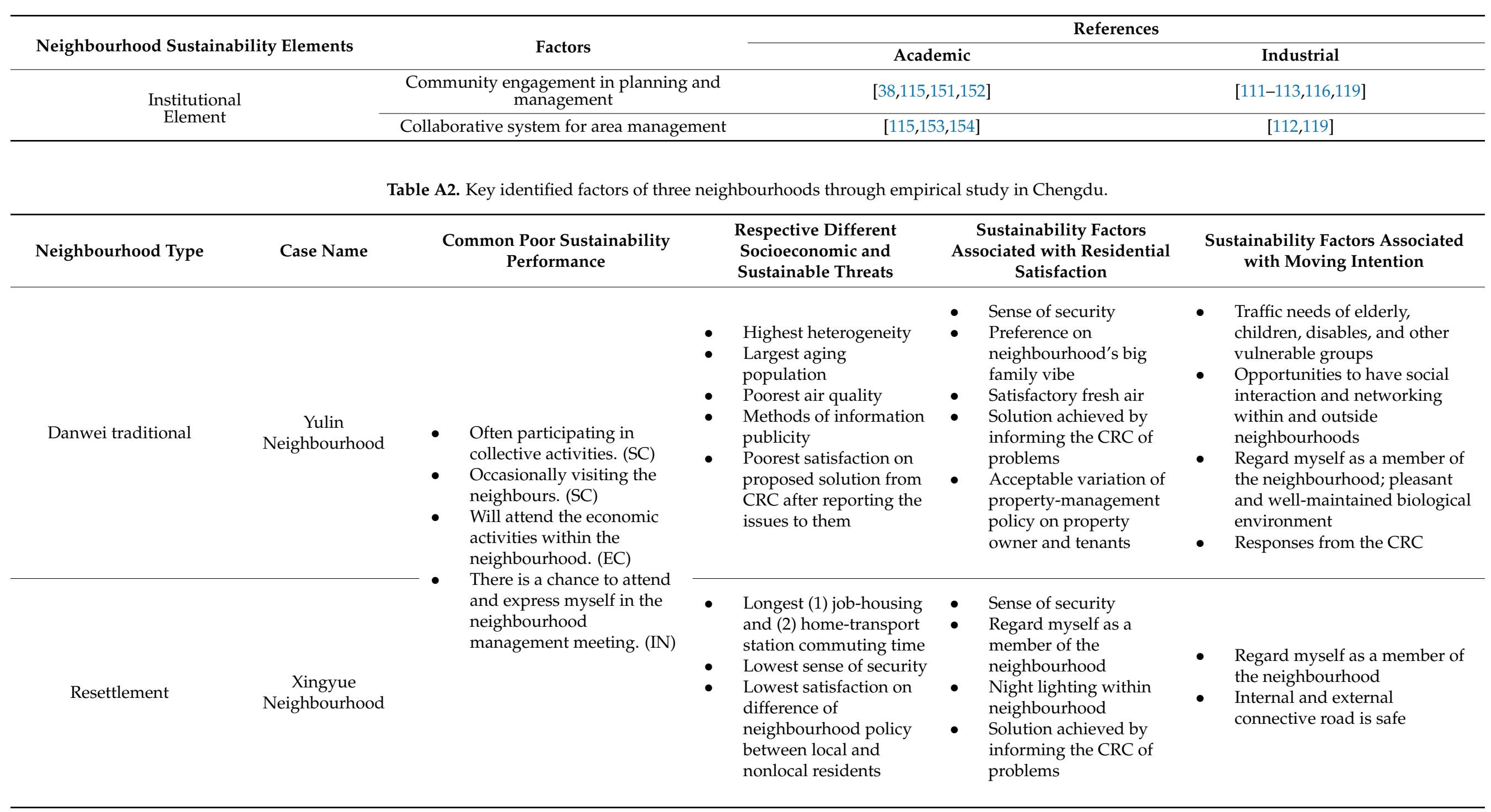


Table A2. Cont.

\begin{tabular}{|c|c|c|c|c|c|}
\hline Neighbourhood Type & Case Name & $\begin{array}{c}\text { Common Poor Sustainability } \\
\text { Performance }\end{array}$ & $\begin{array}{l}\text { Respective Different } \\
\text { Socioeconomic and } \\
\text { Sustainable Threats }\end{array}$ & $\begin{array}{c}\text { Sustainability Factors } \\
\text { Associated with Residential } \\
\text { Satisfaction }\end{array}$ & $\begin{array}{l}\text { Sustainability Factors Associated } \\
\text { with Moving Intention }\end{array}$ \\
\hline Commodity housing & $\begin{array}{c}\text { Jinyang } \\
\text { Neighbourhood }\end{array}$ & & $\begin{array}{ll}\text { - } & \text { Lowest participation } \\
\text { degree in collective } \\
\text { activities } \\
\text { - } \quad \text { Lowest usage rate of } \\
\text { public open space } \\
\text { Highest moving-out } \\
\text { intention } \\
\text { Lowest participation in } \\
\text { economic activities and } \\
\text { satisfaction on economic } \\
\text { training workshop. }\end{array}$ & $\begin{array}{l}\text { - } \quad \begin{array}{l}\text { Sense and habit of } \\
\text { energy saving }\end{array} \\
\text { Clean internal roads and } \\
\text { adequate garbage bins } \\
\text { Responses from the } \\
\text { CRC } \\
\text { Benefits of engaging } \\
\text { external parties in } \\
\text { neighbourhood } \\
\text { development, responses } \\
\text { from the CRC, and } \\
\text { benefits of engaging } \\
\text { external parties in } \\
\text { neighbourhood } \\
\text { development }\end{array}$ & $\begin{array}{ll}\text { - } & \text { Affordable house } \\
\text { - } & \text { Sense of security } \\
& \text { Benefits of engaging external } \\
\text { parties in neighbourhood } \\
\text { development, sense of security }\end{array}$ \\
\hline
\end{tabular}


Table A3. Contextual principles of neighbourhood planning framework.

\begin{tabular}{|c|c|c|c|c|c|c|c|c|}
\hline \multicolumn{3}{|c|}{ Yulin Neighbourhood (Danwei) } & \multicolumn{3}{|c|}{ Xingyue Neighbourhood (Resettlement) } & \multicolumn{3}{|c|}{ Jinyang Neighbourhood (Commodity Housing) } \\
\hline $\begin{array}{l}\text { Principles to Be } \\
\text { Retained (A) }\end{array}$ & $\begin{array}{l}\text { Principles to Be } \\
\text { Enhanced (B) }\end{array}$ & $\begin{array}{c}\text { Principles to Be } \\
\text { Urgently } \\
\text { Assured (C) }\end{array}$ & $\begin{array}{l}\text { Principles to Be } \\
\text { Retained (A) }\end{array}$ & $\begin{array}{l}\text { Principles to Be } \\
\text { Enhanced (B) }\end{array}$ & $\begin{array}{c}\text { Principles to Be } \\
\text { Urgently } \\
\text { Assured (C) }\end{array}$ & $\begin{array}{l}\text { Principles to Be } \\
\text { Retained (A) }\end{array}$ & $\begin{array}{l}\text { Principles to Be } \\
\text { Enhanced (B) }\end{array}$ & $\begin{array}{c}\text { Principles to Be } \\
\text { Urgently } \\
\text { Assured (C) }\end{array}$ \\
\hline
\end{tabular}




\section{References}

1. United Nation (UN). World Urbanization Prospects: The 2014 Revision-Highlights; UN: New York, NY, USA, 2014.

2. López Moreno, E.; Bazoglu, N.; Mboup, G.; Warah, R. State of the World's Cities 2008-2009: Harmonious Cities; UNHABITAT, Earthscan: London, UK, 2008.

3. Lowe, M.; Whitzman, C.; Badland, H.; Davern, M.; Aye, L.; Hes, D.; Butterworth, I.; Giles-Corti, B. Planning Healthy, Liveable and Sustainable Cities: How Can Indicators Inform Policy? Urban Policy Res. 2015, 33, 131-144. [CrossRef]

4. Sharifi, A.; Murayama, A. Viability of using global standards for neighbourhood sustainability assessment: Insights from a comparative case study. J. Environ. Plan. Manag. 2015, 58, 1-23. [CrossRef]

5. Newton, P.W. Liveable and sustainable? Socio-Technical challenges for twenty-First-Century cities. J. Urban Technol. 2012, 19, 81-102. [CrossRef]

6. Neuman, M. The Compact City Fallacy. J. Plan. Educ. Res. 2005, 25, 11-26. [CrossRef]

7. De Haan, F.J.; Ferguson, B.C.; Adamowicz, R.C.; Johnstone, P.; Brown, R.; Wong, T.H. The needs of society: A new understanding of transitions, sustainability and liveability. Technol. Forecast. Soc. Chang. 2014, 85, 121-132. [CrossRef]

8. Folke, C.; Jansson, Å.; Rockström, J.; Olsson, P.; Carpenter, S.R.; Chapin, F.S.; Crépin, A.-S.; Daily, G.; Danell, K.; Ebbesson, J. Reconnecting to the biosphere. Ambio 2011, 40, 719. [CrossRef]

9. Andersson, E.; Tengö, M.; McPhearson, T.; Kremer, P. Cultural ecosystem services as a gateway for improving urban sustainability. Ecosyst. Serv. 2015, 12, 165-168. [CrossRef]

10. Portney, K.E. Taking Sustainable Cities Seriously: Economic Development, the Environment, and Quality of Life in American Cities; MIT Press: Cambridge, MA, USA, 2013.

11. Leach, J.M.; Braithaite, P.A.; Lee, S.E.; Bouch, C.J.; Hunt, D.V.; Rogers, C.D. Measuring urban sustainability and liveability performance: The city analysis methodology. Int. J. Complex. Appl. Sci. Technol. 2016, 1, 86-106. [CrossRef]

12. Mouratidis, K. Is compact city livable? The impact of compact versus sprawled neighbourhoods on neighbourhood satisfaction. Urban Stud. 2017, 55, 2408-2430. [CrossRef]

13. Mitrany, M. High density neighborhoods: Who enjoys them? GeoJournal 2005, 64, 131-140. [CrossRef]

14. Choguill, C.L. Developing sustainable neighbourhoods. Habitat Int. 2008, 32, 41-48. [CrossRef]

15. Girardet, H. Cities People Planet: Liveable Cities for a Sustainable World; Academy Press: West Sussex, UK, 2004.

16. Howley, P.; Scott, M.; Redmond, D. An examination of residential preferences for less sustainable housing: Exploring future mobility among Dublin central city residents. Cities 2009, 26, 1-8. [CrossRef]

17. Kim, J.H.; Pagliara, F.; Preston, J. The Intention to Move and Residential Location Choice Behaviour. Urban Stud. 2005, 42, 1621-1636. [CrossRef]

18. Zhang, Q.; Yung, E.H.K.; Chan, E.H.W. Towards Sustainable Neighborhoods: Challenges and Opportunities for Neighborhood Planning in Transitional Urban China. Sustainability 2018, 10, 406. [CrossRef]

19. Shi, Q.; Yu, T.; Zuo, J.; Lai, X. Challenges of developing sustainable neighborhoods in China. J. Clean. Prod. 2016, 135, 972-983. [CrossRef]

20. Silas, J.; Ernawati, R. Liveability of Settlements by People in the Kampung of Surabaya. In Proceedings of the 19th International CIB World Building Congress, Construction and Society, Brisbane, QUT, Australia, 5-9 May 2013; pp. 1-7.

21. Lu, T.; Zhang, F.; Wu, F. Place attachment in gated neighbourhoods in China: Evidence from Wenzhou. Geoforum 2018, 92, 144-151. [CrossRef]

22. Wang, Z.; Zhang, F.; Wu, F. Neighbourhood cohesion under the influx of migrants in Shanghai. Environ. Plan. A Econ. Space 2017, 49, 407-425. [CrossRef]

23. Ma, J.; Dong, G.; Chen, Y.; Zhang, W. Does satisfactory neighbourhood environment lead to a satisfying life? An investigation of the association between neighbourhood environment and life satisfaction in Beijing. Cities 2018, 74, 229-239. [CrossRef]

24. Wallbaum, H.; Krank, S.; Teloh, R. Prioritizing Sustainability Criteria in Urban Planning Processes: Methodology Application. J. Urban Plan. Dev. 2011, 137, 20-28. [CrossRef]

25. Kates, R.W.; Clark, W.C.; Corell, R.; Hall, J.M.; Jaeger, C.C.; Lowe, I.; Mccarthy, J.J.; Schellnhuber, H.J.; Bolin, B.; Dickson, N.M. Chapter 8. Science 2001, 292, 641-642. [CrossRef]

26. UN-HABITAT. Sustainable Development Goals Report 2016; United Nations Publications: New York, NY, USA, 2016.

27. Grybaitė, V.; Tvaronavičienè, M. Estimation of sustainable development: Germination on institutional level. J. Bus. Econ. Manag. 2008, 9, 327-334. [CrossRef]

28. Ciegis, R.; Ramanauskiene, J.; Martinkus, B. The concept of sustainable development and its use for sustain-ability scenarios. Eng. Econ. 2009, 62, 2.

29. Yigitcanlar, T.; Sipe, N.G.; Evans, R.; Pitot, M. A GIS-Based land use and public transport accessibility indexing model. Aust. Plan. 2007, 44, 30-37. [CrossRef]

30. Gilbert, R.; Stevenson, D.; Girardet, H.; Stren, R. Making Cities Work: Role of Local Authorities in the Urban Environment; Routledge: London, UK, 2013.

31. Yigitcanlar, T.; Kamruzzaman, M.; Teriman, S. Neighborhood sustainability assessment: Evaluating resi-dential development sustainability in a developing country context. Sustainability 2015, 7, 2570-2602. [CrossRef] 
32. Komeily, A.; Srinivasan, R. A need for balanced approach to neighborhood sustainability assessments: A critical review and analysis. Sustain. Cities Soc. 2015, 18, 32-43. [CrossRef]

33. Berardi, U. Sustainability assessment of urban communities through rating systems. Environ. Dev. Sustain. 2013, 15, 1573-1591. [CrossRef]

34. Goodland, R. The concept of environmental sustainability. Annu. Rev. Ecol. Syst. 1995, 26, 1-24. [CrossRef]

35. Engel-Yan, J.; Kennedy, C.; Saiz, S.; Pressnail, K. Toward sustainable neighbourhoods: The need to consider infrastructure interactions. Can. J. Civ. Eng. 2005, 32, 45-57. [CrossRef]

36. Bijoux, D.; Lietz, K.; Saville-Smith, K. Measuring Neighbourhood Sustainability in New Zealand. In Proceedings of the UPE7: World Class Cities-Environmental Impacts and Planning Opportunities, Bangkok, Thailand, 3-5 January 2007.

37. Carmichael, J.; Talwar, S.; Tansey, J.; Robinson, J. Where Do We Want to Be? Making Sustainability Indicators Integrated, Dynamic and Participatory. Community Indic. Meas. Syst. 2005, 178, 178-204. [CrossRef]

38. Meek, J.W. Adaptive intermediate structures and local sustainability advances. Public Adm. Q. 2008, 32, 415-432.

39. Zhang, Q.; Yung, E.H.K.; Chan, E.H.W. Comparison of perceived sustainability among different neighbourhoods in transitional China: The case of Chengdu. Habitat Int. 2020, 103, 102204. [CrossRef] [PubMed]

40. Grogan-Kaylor, A.; Woolley, M.; Mowbray, C.; Reischl, T.M.; Gilster, M.; Karb, R.; Macfarlane, P.; Gant, L.; Alaimo, K. Predictors of Neighborhood Satisfaction. J. Community Pr. 2006, 14, 27-50. [CrossRef]

41. Howley, P.; Scott, M.; Redmond, D. Sustainability versus liveability: An investigation of neighbourhood satisfaction. J. Environ. Plan. Manag. 2009, 52, 847-864. [CrossRef]

42. Hipp, J. What is the 'Neighbourhood' in Neighbourhood Satisfaction? Comparing the Effects of Structural Characteristics Measured at the Micro-neighbourhood and Tract Levels. Urban Stud. 2010, 47, 2517-2536. [CrossRef] [PubMed]

43. Permentier, M.; Bolt, G.; Van Ham, M. Determinants of neighbourhood satisfaction and perception of neigh-bourhood reputation. Urban Stud. 2011, 48, 977-996. [CrossRef]

44. Corrado, G.; Corrado, L.; Santoro, E. On the Individual and Social Determinants of Neighbourhood Satisfaction and Attachment. Reg. Stud. 2013, 47, 544-562. [CrossRef]

45. Marans, R.W.; Rodgers, W. Toward an understanding of community satisfaction. Metrop. Am. Contemp. Perspect. N. Y. 1975, 3 , 299-352.

46. Campbell, A.; Converse, P.E.; Rodgers, W.L. The Quality of American Life: Perceptions, Evaluations, and Satisfactions; Russell Sage Foundation: New York, NY, USA, 1976.

47. Bruin, M.J.; Cook, C.C. Understanding Constraints and Residential Satisfaction Among Low-Income Single-Parent Families. Environ. Behav. 1997, 29, 532-553. [CrossRef]

48. Lu, M. Determinants of Residential Satisfaction: Ordered Logit vs. Regression Models. Growth Chang. 1999, 30, $264-287$. [CrossRef]

49. Parkes, A.; Kearns, A.; Atkinson, R. What Makes People Dissatisfied with their Neighbourhoods? Urban Stud. 2002, 39, 2413-2438. [CrossRef]

50. Sirgy, M.J.; Cornwell, T. How Neighborhood Features Affect Quality of Life. Soc. Indic. Res. 2002, 59, 79-114. [CrossRef]

51. Allen, N.; Haarhoff, E.; Beattie, L. Enhancing liveability through urban intensification: The idea and role of neighbourhood. Cogent Soc. Sci. 2018, 4, 1442117. [CrossRef]

52. Van Kamp, I.; Leidelmeijer, K.; Marsman, G.; De Hollander, A. Urban environmental quality and human well-being: Towards a conceptual framework and demarcation of concepts; a literature study. Landsc. Urban Plan. 2003, 65, 5-18. [CrossRef]

53. Haarhoff, E.; Beattie, L.; Dupuis, A. Does higher density housing enhance liveability? Case studies of housing intensification in Auckland. Cogent Soc. Sci. 2016, 2, 1243289. [CrossRef]

54. Hamersma, M.; Tillema, T.; Sussman, J.; Arts, J. Residential satisfaction close to highways: The impact of accessibility, nuisances and highway adjustment projects. Transp. Res. Part A Policy Pract. 2014, 59, 106-121. [CrossRef]

55. Miller, T.R.; Wiek, A.; Sarewitz, D.; Robinson, J.; Olsson, L.; Kriebel, D.; Loorbach, D. The future of sustainability science: A solutions-oriented research agenda. Sustain. Sci. 2014, 9, 239-246. [CrossRef]

56. Gifford, R.; Comeau, L.A. Message framing influences perceived climate change competence, engagement, and behavioral intentions. Glob. Environ. Chang. 2011, 21, 1301-1307. [CrossRef]

57. Sabin, P. The Bet: Paul Ehrlich, Julian Simon and Our Gamble over Earth's Future; HeinOnline: New York, NY, USA, 2014.

58. Desa, U. Achieving Sustainable Development and Promoting Development Cooperation; Department of Economic and Social Affairs of the United Nations, United Nations Publications: New York, NY, USA, 2008.

59. Speare, A. Residential Satisfaction as an Intervening Variable in Residential Mobility. Demography 1974, 11, 173-188. [CrossRef]

60. Sampson, R.J.; Raudenbush, S.W.; Earls, F. Neighborhoods and Violent Crime: A Multilevel Study of Collective Efficacy. Science 1997, 277, 918-924. [CrossRef] [PubMed]

61. Silver, E.; Miller, L.L. Sources of informal social control in Chicago neighborhoods. Criminology 2004, 42, 551-584. [CrossRef]

62. Permentier, M.; van Ham, M.; Bolt, G. Neighbourhood Reputation and the Intention to Leave the Neighbourhood. Environ. Plan. A Econ. Space 2009, 41, 2162-2180. [CrossRef]

63. Breitung, W. Differentiated neighbourhood governance in transitional urban China: Comparative study of two housing estates in Guangzhou. In Neighbourhood Governance in Urban China; Edward Elgar Publishing: Hong Kong, China, 2014; pp. 145-166. 
64. Li, S.-M.; Zhu, Y.; Li, L. Neighborhood Type, Gatedness, and Residential Experiences in Chinese Cities: A Study of Guangzhou. Urban Geogr. 2012, 33, 237-255. [CrossRef]

65. Zhao, W.; Zou, Y. Un-gating the gated community: The spatial restructuring of a resettlement neighborhood in Nanjing. Cities 2017, 62, 78-87. [CrossRef]

66. Chai, Y. Danwei-based Chinese cities' internal life-space structure: A case study of Lanzhou city. Geogr. Res. 1996, 15, 30-38.

67. Liu, R.; Wong, T.-C. The allocation and misallocation of economic housing in Beijing: Target groups versus market forces. Habitat Int. 2015, 49, 303-315. [CrossRef]

68. Flock, R.; Breitung, W.; Lixun, L. Commodity Housing and the Socio-spatial Structure in Guangzhou. China Perspect. 2013, 2013, 41-51. [CrossRef]

69. Xu, F. Governing China's Peasant Migrants: Building Xiaokang Socialism and Harmonious Society; Routledge: Abingdon, UK, 2009; pp. 50-74.

70. Miao, P. Deserted Streets in a Jammed Town: The Gated Community in Chinese Cities and Its Solution. J. Urban Des. 2003, 8, 45-66. [CrossRef]

71. Ma, L.J.; Wu, F. Restructuring the Chinese City: Changing Society, Economy and Space; Routledge: London, UK, 2004.

72. Zhu, Y.; Breitung, W.; Li, S.-M. The Changing Meaning of Neighbourhood Attachment in Chinese Commodity Housing Estates: Evidence from Guangzhou. Urban Stud. 2012, 49, 2439-2457. [CrossRef]

73. Lee, B.A.; Oropesa, S.; Kanan, J.W. Neighborhood Context and Residential Mobility. Demography 1994, 31, 249-270. [CrossRef]

74. Hirschfield, A.; Bowers, K. The Effect of Social Cohesion on Levels of Recorded Crime in Disadvantaged Areas. Urban Stud. 1997, 34, 1275-1295. [CrossRef]

75. Zhang, M.; Wu, W.; Zhong, W.; Zeng, G.; Wang, S. The reshaping of social relations: Resettled rural residents in Zhenjiang, China. Cities 2017, 60, 495-503. [CrossRef]

76. Zhang, J. The hukou system as China's main regulatory framework for temporary rural-urban migration and its recent changes. Die Erde J. Geogr. Soc. Berl. 2012, 143, 233-247.

77. Fujita, M.; Mori, T. Frontiers of the New Economic Geography. Pap. Reg. Sci. 2005, 84, 377-405. [CrossRef]

78. Bosker, M.; Brakman, S.; Garretsen, H.; Schramm, M. Relaxing Hukou: Increased labor mobility and China's economic geography. J. Urban Econ. 2012, 72, 252-266. [CrossRef]

79. Wang, F.; Liu, Y. Interpreting Chinese Hukou System from a Foucauldian Perspective. Urban Policy Res. 2018, 36, 153-167. [CrossRef]

80. Wu, Y. Chengdu Comprehensively Launch Neighbourhood Planning Action for Covering Ninety Percent of All Neighbourhood Citywide Within Two Years; Sichuan Daily: Chengdu, China, 2018.

81. Seawright, J.; Gerring, J. Case Selection Techniques in Case Study Research: A Menu of Qualitative and Quantitative Options. Case Stud. 2008, 61, II213. [CrossRef]

82. Li, W.; Li, Y.; Geng, W.; Wang, X.; Liu, Y. The Exploration of a Neighborhood Planning Scheme Following the Rule of “Harmonious Coexistence of Pluralism and Difference"-Case Studies of Yulin and Caojiaxiang Neighborhoods in Chengdu. J. Hum. Settl. West China 2015, 30, 61-66.

83. Kotrlik, J.; Higgins, C. Organizational research: Determining appropriate sample size in survey research appropriate sample size in survey research. Inf. Technol. Learn. Perform. J. 2001, 19, 43.

84. Wancata, P.J.; Krautgartner, M.; Alexandrowicz, R.; Meise, U. General Health Questionnaire (GHQ) in general hospitals: Selecting a set of items using a stepwise hierarchical procedure. Int. J. Methods Psychiatr. Res. 2001, 10, 108-117. [CrossRef]

85. Jeong, H.; Lee, W. The level of collapse we are allowed: Comparison of different response scales in Safety Attitudes Questionnaire. Biom. Biostat. Int. J. 2016, 4, 4. [CrossRef]

86. Ansell, C.; Doberstein, C.; Henderson, H.; Siddiki, S.; Hart, P. T Understanding inclusion in collaborative governance: A mixed methods approach. Policy Soc. 2020, 39, 570-591. [CrossRef]

87. Efroymson, M. Multiple Regression Analysis. Mathematical Methods for Digital Computers; Ralston, A., Wilf, H.S., Eds.; John Wiley: New York, NY, USA, 1960.

88. Hocking, R.R. A Biometrics Invited Paper. The Analysis and Selection of Variables in Linear Regression. Biomedicine 1976, 32, 1-49. [CrossRef]

89. Wilson, K.; Elliott, S.; Law, M.; Eyles, J.; Jerrett, M.; Keller-Olaman, S. Linking perceptions of neigh-bourhood to health in Hamilton, Canada. J. Epidemiol. Community Health 2004, 58, 192-198. [CrossRef] [PubMed]

90. Sugiyama, T.; Leslie, E.; Giles-Corti, B.; Owen, N. Associations of neighbourhood greenness with physical and mental health: Do walking, social coherence and local social interaction explain the relationships? J. Epidemiol. Community Health Always 2008, 62, e9. [CrossRef] [PubMed]

91. Sugiyama, T.; Thompson, C.W. Associations between characteristics of neighbourhood open space and older people's walking. Urban For. Urban Green. 2008, 7, 41-51. [CrossRef]

92. Forrest, R.; Yip, N.-M. Neighbourhood and Neighbouring in Contemporary Guangzhou. J. Contemp. China 2007, 16, 47-64. [CrossRef]

93. Chan, E.H.W.; Lee, G.K.L. Critical factors for improving social sustainability of urban renewal projects. Soc. Indic. Res. 2008, 85, 243-256. [CrossRef] 
94. Dempsey, N.; Bramley, G.; Power, S.; Brown, C. The social dimension of sustainable development: Defining urban social sustainability. Sustain. Dev. 2011, 19, 289-300. [CrossRef]

95. Zheng, H.W.; Shen, G.Q.; Wang, H. A review of recent studies on sustainable urban renewal. Habitat Int. 2014, 41, 272-279. [CrossRef]

96. Forrest, R.; Kearns, A. Social Cohesion, Social Capital and the Neighbourhood. Urban Stud. 2001, 38, 2125-2143. [CrossRef]

97. Plas, J.M.; Lewis, S.E. Environmental factors and sense of community in a planned town. Am. J. Community Psychol. 1996, 24, 109-143. [CrossRef]

98. Chen, J.; Wu, Y.; Guo, F.; Wang, H. Domestic property and housing class in contemporary urban China. Neth. J. Hous. Environ. Res. 2018, 33, 91-109. [CrossRef]

99. Rojas, M. Well-Being and the Complexity of Poverty: A Subjective Well-Being Approach; Research Paper; UNU-WIDER, United Nations University (UNU): Tokyo, Japan, 2004.

100. Tipple, G. Housing policy-making in Africa: Ten common assumptions. Habitat Int. 2015, 49, 413-418. [CrossRef]

101. Ruth, M.; Franklin, R.S. Livability for all? Conceptual limits and practical implications. Appl. Geogr. 2014, 49, 18-23. [CrossRef] [PubMed]

102. Yuan, Y.; Kaili, D.; Xinyu, C.; Xinyi, W. A Review of Neighborhood Satisfaction. Urban Dev. Stud. 2018, 25, 10.

103. Bint-E-Waheed, H.; Nadeem, O. Perception of security risk in gated and non-gated communities in Lahore, Pakistan. Neth. J. Hous. Environ. Res. 2020, 35, 897-915. [CrossRef]

104. Sarkar, A.; Bardhan, R. Socio-Physical liveability through socio-spatiality in low-income resettlement archetypes-A case of slum rehabilitation housing in Mumbai, India. Cities 2020, 105, 102840. [CrossRef]

105. Gao, X.; Wang, Z.; Cao, M.; Liu, Y.; Zhang, Y.; Wu, M.; Qiu, Y. Neighbourhood satisfaction in rural resettlement residential communities: The case of Suqian, China. Hous. Stud. 2020, 23, 1-21. [CrossRef]

106. Wang, D.; Wang, F. Contributions of the Usage and Affective Experience of the Residential Environment to Residential Satisfaction. Hous. Stud. 2016, 31, 42-60. [CrossRef]

107. Garcez, C.A.G.; De Souza Vianna, J.N. Brazilian biodiesel policy: Social and environmental considerations of sustainability. Energy 2009, 34, 645-654. [CrossRef]

108. Perry, C.A. Ten Years of the Community Center Movement: Department of Recreation; Russell Sage Foundation: New York, NY, USA, 1921.

109. Alexander, C. A Pattern Language; Oxford University Press: Oxford, UK, 1977.

110. Chiu, R.L.H. Social equity in housing in the Hong Kong Special Administrative Region: A social sustainability perspective. Sustain. Dev. 2002, 10, 155-162. [CrossRef]

111. The Hong Kong Green Building Council. Beam Plus Neighbourhood. 2016. Available online: https://www.hkgbc.org.hk/eng/ beam-plus/beam-plus-neighbourhood/index.jsp (accessed on 19 November 2021).

112. Building Research Establishment. Building Research Establishment Environmental Assessment Method. 2012. Available online: https://www.breeam.com/resources/homes-and-residential/breeam-communities-international-2012/\#: \{\}: text=BREEAM\%20Communities\%20International\%20(2012)\%20is,of\%20large\%2Dscale\%20development\%20plans (accessed on 19 November 2021).

113. United States Green Building Council. Leed for Neighbourhood Development. 2018. Available online: https://www.usgbc.org/ resources/leed-v4-neighborhood-development-current-version (accessed on 19 November 2021).

114. Lew, A.A.; Ng, P.T.; Ni, C.-C.; Wu, T.-C. Community sustainability and resilience: Similarities, differences and indicators. Tour. Geogr. 2016, 18, 18-27. [CrossRef]

115. Turcu, C. Re-thinking sustainability indicators: Local perspectives of urban sustainability. J. Environ. Plan. Manag. 2013, 56, 695-719. [CrossRef]

116. German Sustainable Building Council. Deutsche Gesellschaft für Nachhaltiges Bauen. 2012. Available online: https://www. dgnb-system.de/en/districts/index.php (accessed on 19 November 2021).

117. Tweed, C.; Sutherland, M. Built cultural heritage and sustainable urban development. Landsc. Urban Plan. 2007, 83, 62-69. [CrossRef]

118. Littig, B.; Griessler, E. Social sustainability: A catchword between political pragmatism and social theory. Int. J. Sustain. Dev. 2005, 8, 65. [CrossRef]

119. Japan Sustainable Building Consortium. Comprehensive Assessment System for Built Environment Efficiency (CASBEE). Available online: https://www.ibec.or.jp/CASBEE/english/toolsE_urban.htm (accessed on 19 November 2021).

120. Russo, F.; Comi, A. A classification of city logistics measures and connected impacts. Procedia Soc. Behav. Sci. 2010, 2, 6355-6365. [CrossRef]

121. Cuthill, M. Strengthening the 'social' in sustainable development: Developing a conceptual framework for social sustainability in a rapid urban growth region in Australia. Sustain. Dev. 2010, 18, 362-373. [CrossRef]

122. Martens, P. Sustainability: Science or fiction? Sustain. Sci. Pr. Policy 2006, 2, 36-41. [CrossRef]

123. Ancell, S.; Thompson-Fawcett, M. The Social Sustainability of Medium Density Housing: A Conceptual Model and Christchurch Case Study. Hous. Stud. 2008, 23, 423-442. [CrossRef]

124. Porta, S.; Renne, J.L. Linking urban design to sustainability: Formal indicators of social urban sustainability field research in Perth, Western Australia. Urban Des. Int. 2005, 10, 51-64. [CrossRef] 
125. Barton, H. Sustainable Communities the Potential for Eco-Neighbourhoods. J. Environ. Assess. Policy Manag. 2000,2 , $169-171$. [CrossRef]

126. Burton, E. The compact city: Just or just com pact? A preliminary analysis. Urban Stud. 2000, 37, 1969-2006. [CrossRef]

127. Hopwood, B.; Mellor, M.; O’Brien, G. Sustainable development: Mapping different approaches. Sustain. Dev. 2005, 13, 38-52. [CrossRef]

128. Lyndhurst, B. Research Report 11: Environmental Exclusion Review; Office of the Deputy: London, UK, 2004.

129. Lyndhurst, B. Building Research Establishment. Building Research Establishment Environmental Assessment Method for Communities. 2004. Available online: https:/ / www.breeam.com/communitiesmanual/ (accessed on 14 July 2021).

130. Macintyre, S.; Maciver, S.; Sooman, A. Area, class and health; should we be focusing on places or people? And health; should we be focusing on places or people? J. Soc. Policy 1993, 22, 213-234. [CrossRef]

131. Bramley, G.; Power, S. Urban form and social sustainability: The role of density and housing type. Environ. Plan. B Plan. Des. 2009, 36, 30-48. [CrossRef]

132. Morris, N. Health, Well-Being and Open Space; Edinburgh College of Art and Heriot-Watt University: Edinburgh, UK, 2003.

133. Rogers, Z.; Bragg, E. The Power of Connection: Sustainable Lifestyles and Sense of Place. Ecopsychology 2012, 4, 307-318. [CrossRef]

134. Yung, E.H.K.; Chan, E.H.W.; Xu, Y. Sustainable Development and the Rehabilitation of a Historic Urban District-Sustainability in the Case of Tianzifang in Shanghai. Sustain. Dev. 2014, 22, 95-112. [CrossRef]

135. Buys, L.; Barnett, K.R.; Miller, E.; Bailey, C. Smart housing and social sustainability: Learning from the residents of Queensland's Research House. Aust. J. Emerg. Technol. Soc. 2005, 3, 43-57.

136. Green, G.; Grimsley, M.; Stafford, B. The Dynamics of Neighbourhood Sustainability; Joseph Rowntree Foundation: New York, NY, USA, 2005.

137. De Jong, M.; Joss, S.; Schraven, D.; Zhan, C.; Weijnen, M. Sustainable-Smart-Resilient-Low carbon-Eco-Knowledge cities; making sense of a multitude of concepts promoting sustainable urbanization. J. Clean. Prod. 2015, 109, 25-38. [CrossRef]

138. Caragliu, A.; Del Bo, C.F.M.; Nijkamp, P. Smart Cities in Europe. J. Urban Technol. 2011, 18, 65-82. [CrossRef]

139. Young, S.; Church, C. The United Kingdom Mainstreaming, Mutating or Expiring? Sustainable Communities in Europe; Routledge: London, UK, 2014.

140. Zhao, P.; Lü, B.; de Roo, G. Impact of the jobs-housing balance on urban commuting in Beijing in the transformation era. J. Transp. Geogr. 2011, 19, 59-69. [CrossRef]

141. Zhang, X.; Cheng, J.; Wu, S. Evaluating community accessibility for sustainable urban regeneration: A conceptual framework. In Proceedings of the 5th International Conference on Responsive Manufacturing-Green Manufacturing (ICRM 2010), Ningbo, China, 11-13 January 2010; pp. 11-13.

142. Dales, J.H. Pollution, Property \& Prices: An Essay in Policy-Making and Economics; Edward Elgar Publishing: Cheltenham, UK, 2002.

143. Zhang, C.Z.; Genovese, P.V.; LI, J.W.; Teng, R.Y. The analysis of international green residential district estimate system: Taking the LEED, Chinese ecological residential technology assessment manual and others for example. Sichuan Build. Sci. 2013, $39,2$.

144. WilliamS, K.; Dair, C. A framework of sustainable behaviours that can be enabled through the design of neighbourhood-scale developments. Sustain. Dev. 2007, 15, 160-173. [CrossRef]

145. Stubbs, M. Car Parking and Residential Development: Sustainability, Design and Planning Policy, and Public Perceptions of Parking Provision. J. Urban Des. 2002, 7, 213-237. [CrossRef]

146. Messari-Becker, L.; Mettke, A.; Knappe, F.; Storck, U.; Bollinger, K.; Grohmann, M. Recycling concrete in practice-A chance for sustainable resource management. Struct. Concr. 2014, 15, 556-562. [CrossRef]

147. Gruis, V.; Visscher, H.; Kleinhans, R.J. Sustainable Neighbourhood Transformation; IOS Press: Amsterdam, The Netherlands, 2006; Volume 11.

148. Zhu, Y.; Lin, B. Sustainable housing and urban construction in China. Energy Build. 2004, 36, 1287-1297. [CrossRef]

149. Siew, R.Y.J. A review of sustainability reporting tools (SRTs) for communities. Int. J. Sustain. Constr. Eng. Technol. $2014,5,39-52$.

150. Carmichael, J.; Talwar, S.; Tansey, J.; Robinson, J. Community Indicators Measuring Systems; Routledge: London, UK, 2005; pp. 178-204.

151. Ratcliffe, P. "Race", Ethnicity and Housing Decisions: Rational Choice Theory and the Choice-Constraint Debate. Rational Choice Theory: Resisting Colonisation; Routledge: London, UK, 2000.

152. Pendlebury, J.; Townshend, T.; Gilroy, R. The Conservation of English Cultural Built Heritage: A Force for Social Inclusion? Int. J. Heritage Stud. 2004, 10, 11-31. [CrossRef]

153. Bäckstrand, K. Multi-stakeholder partnerships for sustainable development: Rethinking legitimacy, accountability and effectiveness. Eur. Environ. 2006, 16, 290-306. [CrossRef]

154. Kearns, A.; Forrest, R. Social Cohesion and Multilevel Urban Governance. Urban Stud. 2000, 37, 995-1017. [CrossRef] 